\title{
CUSTOM AND TRADITION VERSUS REASON IN MODERN SECULAR AND RELIGIOUS MORAL REASONING AND IN MODERN CONSTITUTIONAL LAW R. Randall Kelso
}

\section{Introduction: Custom and Tradition Versus Faith in Progress Based Upon Reason}

In a speech on October 6, 2005, former Vice-President Al Gore noted that the American tradition has always been one of reasoned debate about moral values - the "Rule of Reason." He stated:

Our Founders, probably the most literate generation in all of history, used words with astonishing precision and believed in the Rule of Reason. Their faith in the viability of Representative Democracy rested on their trust in the wisdom of a well-informed citizenry... . The values that Americans had brought from Europe to the New World had grown out of the sudden explosion of literacy and knowledge after Gutenberg's disruptive invention broke up the stagnant medieval information monopoly and triggered the Reformation, Humanism, and the Enlightenment and enshrined a new sovereign: the "Rule of Reason." Indeed, the selfgoverning republic they had the audacity to establish was later named by the historian Henry Steele Commager as "the Empire of Reason."

Gore then asked whether that tradition was being undermined by recent trends in media and politics.

This concern about the relationship between moral values and reason is central to any understanding of moral dialogue and debate. Stated briefly, moral reasoning refers to an effort to identify through reasoning how persons ought to behave. Sometimes in philosophy this has been referred to as a search for "the good." Of course, ideas on what is good have differed from one society to another and have changed from time to time within individual societies. Some persons judge what is right in terms of following the customs of neighbors and friends in the local community, including customary notions of morality as reflected in traditional religious doctrine. Other persons judge rightness by following either the letter or the purpose of majority-supported rules in society at large. Others may judge rightness by using only rules that have emerged from a process of reasoned choice. Still others may rely on a system that derives rules rationally, starting from a general premise such as "love of neighbor as oneself" or "treat persons with equal concern and respect."

Naturally, any individual's views on what is ideal may undergo change in response to economic developments, developments in science and technology, ideas produced by the culture, and interaction with other societies in the world, as well as be influenced by personal experiences. Nevertheless, among each of the approaches noted above there is one great divide. Some approaches base moral reasoning on existing customs, traditions, or societal rules. Others base moral reasoning

1 See Text of Gore Speech at Media Conference (Oct. 6, 2005) (internet search using key words in the cited quote from the speech).

2 The classic use of this terminology is by Plato, who defined "the good as the highest object of knowledge,"in The Republic of Plato, Chapter XXIII, and by Aristotle, who defined "the good as the aim of action" in his Nicomachean Ethics, Book I. 
on some form of rational deliberation independent of existing customs, traditions, and rules.

Many commentators have phrased the contemporary debates over values, the so-called "Culture Wars," as a debate between religious and secular ideologies. This is not an accurate way to describe the debate. The real debate is between traditional ideologies, whether religious or secular, which reflect customary or traditional norms, versus progressive ideology, whether religious or secular, which reflect rational deliberation about moral reasoning.

For example, the traditional view of Aristotle, the traditional view of the Catholic Church, and the traditional view of many Protestant denominations in pre-Civil War America, particularly in the South, supported the institution of slavery. Jefferson Davis, President of the Confederate States of America, stated, "[Slavery] is sanctioned in the Bible, in both Testaments, from Genesis to Revelation. . . . It has existed in all ages, has been found among the people of the highest civilization, and in nations of the highest proficiencies in the arts"; a prominent reverend at the time, Reverend R. Furman, D.D., Baptist, of South Carolina, reflecting the view of many Southerners, similarly noted, "The right of holding slaves is clearly established in the Holy Scriptures, both by precept and example." ${ }^{3}$ In contrast, the progressive ideology of the Enlightenment tradition, particularly as encapsulated in the Declaration of Independence, coupled with the progressive views of "Northern evangelistic Protestantism," supported the abolitionist movement. ${ }^{4}$

The debate over slavery was thus not a religious versus secular debate, but was a debate among various traditional views upholding the long-standing practice of slavery on customary or traditional grounds versus progressive views rejecting the morality of slavery based on the observation of reason that all persons are human and thus equally entitled to basic human rights. The traditional religious view, of course, focused on the many passages in the Bible which refer without unfavorable comment to the then-existing practice of slavery, while the progressive, reasoned interpretation of the Bible focused on the general statements of Jesus and St. Paul concerning love, the equality of all persons, and logical derivations from the Golden Rule of treating one's fellow humans as one expects to be treated by others. ${ }^{5}$ As phrased in Galatians 3:28, "There is neither Jew nor Greek, there is neither bond nor free, there is neither male nor female: for ye are all one in Jesus Christ."

The same dynamic applied during the $20^{\text {th }}$ century to the issues of segregation and bans on interracial marriage. The traditional view supported such institutions based on a traditional reading of the Bible, as reflected in the state court opinion in Loving v. Virginia, which stated, "Almighty God created the races white, black, yellow, malay, and red, and he placed them on separate continents.

3 See What the Bible Says About Human Slavery 1 (www.religioustolerance.org/ sla_bibl.html) (quoting Jefferson Davis and Reverend Furman).

4 See generally Daniel Farber \& Suzanna Sherry, A History of the American Constitution 361-83 (2d ed. 2005); David F. Forte, Spiritual Equality, The Black Codes, and the Americanization of the Freedmen, 43 Loy. L. Rev. 569, 573-80 (1998) (“Northern evangelistic Protestantism”).

5 See generally Michael V. Hernandez, A Flawed Foundation: Christianity's Loss of Preeminent Influence on American Law, 56 Rutgers L. Rev. 625, 672-83 (2004). 
And but for the interference with his arrangement there would be no cause for such marriages. The fact that he separated the races shows that he did not intend for the races to mix." ${ }^{6}$ The progressive Enlightenment view, as well as the progressive Christian view, rejected this justification for racial discrimination. From the Enlightenment viewpoint, long-standing tradition does not make a particular practice moral that denies individuals their "unalienable rights [to] life, liberty, and the pursuit of happiness." As Justice Kennedy noted in Lawrence v. Texas, " [T] he fact that a governing majority in a State has traditionally viewed a particular practice as immoral is not a sufficient reason for upholding a law prohibiting the practice; neither history nor tradition could save a law prohibiting miscegenation from constitutional attack." "7 From the progressive Christian viewpoint, the Galatians passage that we are "all one in Jesus Christ" also makes such racial discrimination immoral.

Many examples of the same dynamic throughout world history can be given. For example, the traditional Christian view opposed Galileo's contention that the earth moved around the sun. The Enlightenment faith in science, and the modern Christian view, accept Galileo's scientific findings as accurate. Passages in the Bible regarding the earth not moving and the sun revolving around the earth are viewed from the modern perspective as mere reference to certain historical views existing in the ancient world that are not authoritative.

In each of these cases, even those who originally held the traditional view have come to acknowledge that the progressive view is just. On these issues, no major religious or secular tradition today attempts to defend the concrete practices of the past supporting slavery, or segregation, or antimiscegenation laws, or opposition to the cosmology of Copernicus, Galileo, and Newton. On the other hand, on some issues, like the ordination of women, there is still a split among major religious traditions, with the Catholic Church still clinging to the historical refusal to ordain women, while Protestant religions, with different degrees of enthusiasm, ${ }^{8}$ have long-since moved to the progressive view of Galatians that "there is neither male nor female: for ye are all one in Jesus Christ," which supports the ordination of women. The Catholic Church has sometimes used the concrete fact that all of the 12 disciples were men to support the refusal to ordain women. But the fact is that all the disciples were of Middle Eastern descent, and yet that has never stopped there being priests of other ethnicities. Further, both race and gender were stated by Christ to be irrelevant, since "there is neither Jew nor Greek, there is neither bond nor free, there is neither male nor female: for ye are all one in Jesus Christ."

In general, the secular tradition of the Enlightenment seems predisposed to adopt the perspective of reason on most moral issues, since the Enlightenment view is based on faith in man's progress through the application of reason. Thus, persons approaching moral reasoning from the Enlightenment tradition are typically more willing to discard concrete practices of societies in favor

6 Loving v. Virginia, 388 U.S. 1, 3 (1967) (quoting the state trial judge opinion in Loving).

$7 \quad$ Lawrence v. Texas, 539 U.S. 558, 578-79 (2003), quoting Bowers v. Hardwick, 478 U.S. 214, 216 (1986) (Stevens, J., joined by Brennan \& Marshall, JJ., dissenting).

8 See, e.g., Elisabeth F. Wendorff, Employment Discrimination and Clergywomen: Where the Law Has Feared to Tread, 3 S. Cal. Rev. L. \& Women's Stud. 135 (1993). 
of principles derived directly from reason. Religious traditions tend to be more predisposed to rely on customs of communities or traditions in society at large. This is particularly true for religions with a greater centralized bureaucracy, like the Catholic Church. Thus, it is not surprising that the Catholic Church would cling longer to historical practices like the refusal to ordain women, or the celibacy of priests, than Protestant traditions.

However, as the examples of slavery, segregation, and anti-miscegenation laws indicate, religious natural law reasoning is not synonymous with tradition. The pervasiveness of anti-Semitism among traditional Christian doctrine, but its rejection today, discussed in Part II, Section C, is another such example. On each of these issues, there is a progressive interpretation of the Bible based on reasoning from the general precepts in the Bible regarding love, the Golden Rule, and the Galatians precept that "we are all one in Jesus Christ," which transcends the reliance on the concrete customs of the past, or a traditional reading of the literal passages in the Bible, which supported slavery, segregation, anti-miscegenation laws, and anti-Semitism.

For this reason, as elaborated in Part II below, contemporary debates on social issues are best understood as debates among moral reasoning based upon customs and traditions versus moral reasoning based upon reason, rather than a debate between religious versus secular perspectives. Similarly, as discussed in Part III, a major difference among Supreme Court Justices is the extent to which broad terms in the Constitution, like liberty or equality, should be read consistent with customary and traditional beliefs, a view supported by Justices Scalia and Thomas, or should be read in light of the demands of reason, the position of Justices Stevens, Kennedy, Souter, Ginsburg, and Breyer. It is too early to tell how the Justices replacing Chief Justice Rehnquist and Justice O'Connor will resolve this issue in cases coming before them. Assuming a majority of Supreme Court Justices remain committed to doctrinal development consistent with reason, Part IV sketches aspects of current constitutional doctrine, and possible doctrinal development in the future, consistent with that vision.

Two main reasons account for the differences between many traditional views versus progressive moral ideals based on reason. The first is an inadequate understanding and embrace of scientific truths, like with the Catholic Church's original demand that Galileo recant his scientific findings. The second reason is the failure of some individuals to take fully into account other individual's perspectives. Because of this, some individuals predominantly take into account only the perspective of their local community, which may be predominantly one race, or one religion, or dominated in terms of societal power structures by one sex, typically the male. From that perspective, racial, or religious, or gender discrimination against less powerful groups in society may follow naturally. If such discrimination is held in enough communities, it may become part of the moral beliefs of the nation generally. For persons engaged in rational thought, however, who take other person's perspectives fully into account, such racial, or religious, or gender discrimination is always immoral.

As discussed in Part II, these differences between less rational customs and traditions versus reason have played out on at least 10 different issues over the last 600 years. Organized by whether the predominant flaw in customary or traditional reasoning was an inadequate embrace of scientific truth, or a failure to see things fully from another's perspective, and numbered in order from the earliest issue when the progressive rational perspective became mainstream, to latter issues where 
the progressive rational perspective is just emerging as the dominant moral view in culturally and economically advanced societies, these ten issues are:

Inadequate Embrace of Scientific Truths

(1) Galileo v. Recantation

(2) Flawed Economics, e.g., Money By Nature Barren \& Anti-Semitism

(3) Left-Handed v. Right-Handed Discrimination

(8) Evolution v. Creationism/Intelligent Design

(9) Existence/Creation of "Human Soul"

Birth Control

Stem-Cell Research

Abortion
Don't See Things From Other's Perspectives

(4) Slavery/Apartheid

(5) Segregation/Anti-Miscegenation Laws

(6) Limited Women's Rights

(7) Religious Discrimination

Protestant v. Catholic

Anti-Semitism

Sunni v. Shiite

Moslem v. Hindu

Believer v. Non-Believer

(10) Sexual Orientation v. Preference \& Anti-Gay Rights

Of course, for many of these issues, both reasons combined to some extent to justify the discrimination. For example, inadequate understanding of racial genetics helped support the view that slavery against African-Americans was moral, based on the view of their genetic inferiority. Predominantly, though, slavery was based on a failure to view the status of enslaved AfricanAmericans from the same perspective as the status of free whites. The enlightened response to this, seeing things from the other person's perspective in addition to one's own, was Abraham Lincoln's famous oft-quoted observation, "As I would not be a slave, so I would not be a master."9

Similarly, part of the discrimination against persons based on sexual orientation is a product of the majority of straight persons in any community failing to take into account, and see things from, the perspective of gay persons. Historically, the predominant justification for the discrimination seems to have been an inadequate scientific understanding that being gay is predominantly the product of a naturally occurring genetic variation, like being left-handed or right-handed, rather than an abnormal sexual preference lifestyle choice. Aspects of this are discussed at Part II, Section D.

On balance, on all 10 of these issues, Western European societies and Canada, with their more educated populace, have moved, or are in the process of moving, to the perspective of reason on all these issues. Even with respect to gay rights, all of these countries allow gays to serve openly in the military, and the Netherlands, Belgium, Spain, and Canada have officially adopted gay marriage statutes, with other Western European countries having some extensive form of civil unions.

Societies with much weaker educational systems, like those in Africa and the Middle East, still reflect traditional attitudes on many of these issues, including limited rights for women; religious discrimination, including anti-Semitism; and pervasive discrimination based upon sexual orientation. As discussed in Part II, Section A, individuals at less advanced stages of cognitive development are likely to reason more from the perspective of concrete customs and traditions because they are most

9 See, e.g., Barbara Jordan, Keynote Address: 1996 Democratic National Convention, 5 Tex. J. Women \& L. 189, 191 (1996) (quote of Lincoln during the 1858 Lincoln/Douglas debates). 
comfortable with less cognitively advanced "concrete operational thought." As discussed with respect to America in Part III, the "Blue States" are closer to the Western European and Canadian model on all these issues; the "Midwest, Plains, and Western Red States" are next in line; and the "Deep South Red States," which historically have had weaker educational systems, have usually had to have the progressive perspective of reason imposed upon them to overcome their existing customs and traditions. This has occurred either by the Civil War, with respect to slavery, or by Supreme Court decisions since 1954, with respect to segregation; anti-miscegenation laws; more equal rights for women, which were initially blocked when the "Deep South Red States" refused in mass to ratify the Equal Rights Amendment during the 1970s; abortion rights; and, increasingly, issues of equal civil rights for gays and lesbians.

The example of Spain and the issue of gay marriage helps make it clear that these issues are best conceived not as religious versus secular debates, but rather traditional versus modern progressive rational views. Spain is one of the most Catholic nations on earth, and most Spaniards are devout Catholics. Nevertheless, the majority of Spaniards now support equal rights for gays to marry based on giving gay persons "equal concern and respect" and not treating them as "second-class citizens." This decision does not make Spaniards any less religious. It just means that like rejecting the traditional Catholic doctrine that supported slavery during the Middle Ages, or called for Galileo's recantation, or was pervasively anti-Semitic, or limits birth control options and use of contraceptives even today, the majority of Spaniards have moved to a more progressive understanding of religion and the message of Christ. While over the last 600 years Popes have brought the Catholic Church into the progressive era on slavery, and Galileo, and anti-Semitism, they have not yet done that on theories of evolution versus intelligent design, or birth control, stem-cell research, and abortion, as discussed at Part II, Section C, or the issue of gay rights, as discussed at Part II, Section D.

\section{The Form or Shape of Moral Deliberation Based Upon Reason: "Equal Concern and Respect" or "Love of Neighbor as Oneself"}

\section{A. The Philosophic Base of Rational Moral Thought}

The question of the morality of "egotism" or "self-interest" is, of course, central to moral discourse. Some moral philosophers have taken the position that egotism or self-interest is rational, and have built their moral systems on self-interest. Thomas Hobbes in the $17^{\text {th }}$ century, ${ }^{10}$ Friedrich Nietzsche in the $19^{\text {th }}$ century, ${ }^{11}$ and Robert Nozick in the $20^{\text {th }}$ century, ${ }^{12}$ are examples of this.

10 See 1 Encyclopedia of Ethics 546 (Becker \& Becker eds. 1992) (“[Hobbes'] argument is concerned to persuade people to institute and maintain a sovereign. Given Hobbes' psychological theory, people will do this only if they believe it is in their self-interest. Hence, self-interest is all that can yield obedience to the laws of nature and political obedience to the sovereign."), discussing Thomas Hobbes, Leviathan (1651).

11 See 2 Encyclopedia of Ethics 906 (Becker \& Becker eds. 1992) ("The morality of an abundant, creative, and egoistic power that Nietzsche describes as the origin of human evolution ultimately becomes the norm of his own ethics."), discussing Friedrich Nietzsche, Beyond Good and 
This conclusion that rational thought is self-interested, and thus self-interest can form the basis for moral action, is consistent with early stages of cognitive development in human beings, what cognitive developmental psychologists have called "preoperational thought." For young children, typically from ages 2 to 7 , the child is able to represent objects and events symbolically, and not just act towards them but think about them. ${ }^{13}$ However, the child's thought is characterized by egocentricism. The child finds it difficult to understand how anyone can see things from a point of view different than the child's own view. As Jean Piaget, a leader in cognitive developmental psychology, stated, "[T] he child supposes that every one necessarily thinks like himself . . . [H] is logic lacks exactitude and objectivity . . . because the social impulses of maturer years are counteracted by an innate egocentricity." 14 At this stage, "The preoperational child is completely egocentric. Although he is beginning to take a greater interest in the objects and people around him, he sees them from only one point of view: his own." 15

Most moral philosophers reject the view that self-interest is moral. By various ways, or "prisms" as they can be called, these philosophers banish egocentricism from their account of proper moral reason. One way this has been done is to appeal to customary or traditional moral values held by individuals in society which transcend self-interest and egotism. A second way is by use of various "prisms" that appeal to a more sophisticated understanding of the demands of reason.

The use of customs or traditions to transcend individual egocentricism is consistent with the next major stage of cognitive developmental thought in individuals, "concrete operational thought." As defined by cognitive developmental psychologists, concrete operational thought can only reason about what is concretely observed, rather than engage in abstract reasoning thought processes. ${ }^{16}$ Such concrete operational thought underlies adolescent peer group mentality moral reasoning, which is based on concrete customs of local friends and one's community. ${ }^{17}$ In contrast, educated adults fully embrace the final stage of cognitive development, "formal operational thought," and its ability

\section{Evil (1886).}

12 Robert Nozick, Anarchy, State \& Utopia 302 (1974) ("The model is designed to let you choose what you will, with the sole constraint being that others may do the same for themselves and refuse to stay in the world you have imagined.").

13 See Jean Piaget, The Psychology of Intelligence 123-39 (1950). This terminology represents a summary. For example, Piaget broke down this stage of pre-operational thought into two major sub-stages: preconceptual thought (from two to four years of age) and intuitive thought (from four to seven years of age). Id. at 123.

14 Jean Piaget, The Child's Concept of the World 33 (1929).

D. Singer \& T. Revenson, A Piaget Primer: How a Child Thinks 19 (1979).

16

See Piaget, supra note 13, at 139-47.

17

See generally Jean Piaget, The Moral Judgment of the Child 139-47 (1965). 
to engage in truly abstract thought. Such formal operational thought permits the full ability mentally to take other persons' perspectives and reason logically in light of those perspectives in addition to one's own concrete perspective. ${ }^{18}$ From this more sophisticated understanding of reason, develops a requirement of giving all individuals equal concern and respect.

For example, the Scottish Enlightenment philosophers in the $18^{\text {th }}$ century, like David Hume, Frances Hutcheson, and Adam Smith, rejected Hobbes' rational self-interest in favor of responsible "moral sense" reasoning. ${ }^{19}$ As Adam Smith stated in The Theory of Moral Sentiments, ${ }^{20}$ an individual ought to act like an "impartial spectator," giving equal weight to others' interests as well as one's own. This is a version of the basic biblical principle of "love of neighbor as oneself." Adam Smith stated:

In the same manner, to the selfish and original passions of human nature, the loss or gain of a very small interest of our own, appears to be of vastly more importance . . . than the greatest concern of another with whom we have no particular connection. ... Before we can make any proper comparison of those opposite interests, we must change our position. We must view him, neither from our own place nor yet from his, but from the place and with the eyes of a third person who has no particular connection with either, and who judges impartially between us. $\ldots$

When the happiness or misery of others depends in any respect upon our conduct, we dare not, as self-love might suggest to us, prefer the interest of one to that of many. The man within immediately calls to us, that we value ourselves too much and other people too little, and that by doing so we render ourselves the proper object of contempt and indignation of our brethren. ${ }^{21}$

Immanuel Kant's view that reason compels an individual "to act only in accordance with a principle that one could will to be a universal law" and for everyone "to treat others always as end-inthemselves, and not as a means to your ends" also rejects egotism, and thus is in direct contrast to Nietzsche's egocentricism. ${ }^{22}$ Likewise, John Rawls' principle that justice derives from individuals

18 See generally Jean Piaget, Logic and Psychology (1952), in The Essential Piaget 461-62 (Howard E. Gruber \& J. Jacques Voneche eds. 1977).

19 See, e.g., Garry Wills, Inventing America: Jefferson's Declaration of Independence 193-201 (1978), discussing, inter alia, David Hume, An Inquiry Concerning the Human Understanding (1748); David Hume, An Inquiry Concerning the Principles of Morals (1751); Adam Smith, The Theory of Moral Sentiments (1759).

20 Smith, supra note 19, at 221, cited in R. Randall Kelso \& Charles D. Kelso, Studying Law: An Introduction 517 (West Pub. Co. 1984).

21 Id. at 221, 223, cited in Kelso \& Kelso, supra note 20, at 517-18.

22 See 1 Encyclopedia of Ethics 666 (Becker \& Becker eds. 1992) ("Kant's categorical imperative, .. . 'Act only on a maxim which you can at the same time will to be a universal law.' ... [As a corollary, 'Act always so that you treat humanity, in your own person or another, never 
agreeing upon rules from "an original position" where no individual will be favored rejects Nozick's egocentric approach. ${ }^{23}$ A similar such enterprise is John Finnis' account of basic human goods, like knowledge and friendship, leading to a rejection of egotism in favor of loving one's neighbor as oneself as part of "integral human fulfillment." ${ }^{24}$ Ronald Dworkin's principle of "equal concern and respect" for others, based upon Dworkin's view of the best interpretation of the existing moral principles of Western industrialized societies, represents a similar rejection of egocentric thought. ${ }^{25}$

The problem with all of the above accounts occurs when the authors do not stop their moral reasoning with the basic principle upon which they all agree - the principle of "love of neighbor as oneself," that is, give "equal concern and respect" to others by behaving like an "impartial spectator." Instead, the authors filter through whichever prism they have constructed for affirming this central moral principle a host of moral dilemmas from which they derive a host of collateral moral principles unrelated to the principle of "love of neighbor." Because each prism filters these other problems differently, the authors disagree on these other dilemmas. Each author then attempts to convince the reader that the author's prism is the right one, relying in part on the fact that the author's prism handled in an intuitively attractive way the rejection of the egotistic self-interest problem.

For example, because Dworkin derives his principle of "equal concern and respect" from "the best justification available for the doctrines and devices of law as a whole, ${ }^{, 26}$ he is logically committed to affirming certain doctrines that are part of that "best justification" that may not be compatible with the generic principle of equal concern and respect. To this extent, Dworkin's ultimate justification of moral norms is dependent, in part, on the concrete practices still reflected in existing doctrine, which is why his approach is ultimately a version of political natural law, based on existing political and legal doctrine, not a pure ethical natural law theory based on reason alone.

John Rawls derives his rejection of egocentric self-interest from placing self-interested parties in a hypothetical "original position" and then derives from this a "difference principle" that allows social and economic inequalities only when they benefit the least advantaged individual in society. This "difference principle" is a product of the hypothetical "original position." 27 Without regard to whether the "difference principle" is rationally derivable from the reasoning of self-interested parties

merely as a means but also at the same time as an end in itself."'), discussing Immanuel Kant, Groundwork of the Metaphysics of Morals (1785); Immanuel Kant, Critique of Pure Reason (1788).

23 John Rawls, A Theory of Justice 17-22 (1971) (“The Original Position and Justification”).

24 See generally John Finnis, Natural Law and Natural Rights 59-99 (1980).

25 Ronald Dworkin, Taking Rights Seriously 272-73 (1977) (“Government must not only treat people with concern and respect, but with equal concern and respect.”).

26 Ronald Dworkin, Law's Empire 400 (1986) (“'[P]resent law, for Hercules, consists in the principles that provide the best justification ... for the doctrines and devices of law as a whole.").

27 Rawls, supra note 23, at 17-22. 
in an "original position," 28 neither the difference principle nor the original position have anything to do with straightforward moral reasoning about the non-egotistic practice of giving other individuals equal concern and respect.

In like manner, John Finnis' prism involves postulating seven basic human goods and nine aspects of "practical reasonableness" by which to balance these goods. ${ }^{29}$ This postulating of goods, however, is the product of Finnis' intuitions about what would seem reasonable to him and others, and is not based on any rational derivation from first principles. At the end of the day, his seven basic goods do not embody a straightforward rational analysis about the non-egotistic practice of giving other individuals equal concern and respect.

Similarly, Kant's principle of "universalizability," that is, self-interested parties should act "only in accordance with a principle that one could will to be a universal law," is an artificial device that is not synonymous with a straightforward analysis of non-egocentric thought. Indeed, as Philosopher R.M. Hare has argued, the principle of "universalizability" is as consistent with an act utilitarian or rule utilitarian moral philosophy as it is with Kantian moral philosophy. ${ }^{30}$

\section{B. The Enlightenment Form or Shape of Rational Moral Reasoning}

Two things need to be said about all the previous attempts discussed in the last section at trying to provide rational principles of moral judgment. First, given our contemporary understanding of modern physics, no prism is necessary to affirm the central principle that rational behavior is not self-centered, but must conform to the logic of the "impartial spectator." Reason, or rational thought, is that thought which conforms to physical reality. For example, it is rational to believe that $2+2$ $=4$ because that is what physical reality confirms. Unlike a Newtonian understanding of physics, where self-centered measurement and reflection was thought to be adequate to comprehend accurately physical reality, in an Einsteinian universe of relativity, it is necessary to give equal concern and respect to others' frames of reference in addition to one's own in order to give an adequate account of the physical universe. To be rational in an Einsteinian universe, therefore, requires rejection of an egotistic preference for one's own frame of reference. ${ }^{31}$

Children, who have not yet developed formal operational thought reasoning capacities, and thus who do not yet have the cognitive abilities to see things fully from others' frames of reference, as noted

28 See, e.g., Richard A. Posner, Reply to Critics of the Problematic Nature of Moral and Legal Theory, 111 Harv. L. Rev. 1796, 1819 (1998) (difference principle profoundly "risk-adverse"); C. Edwin Baker, Outcome Equality or Equality of Respect: The Substantive Content of Equal Protection, 131 U. Pa. L. Rev. 933, 949-60 (1983) (difference principle not rationally derivable).

29 Finnis, supra note 24, at 59-126.

30 R.M. Hare, Moral Thinking: Its Levels, Method and Point 107-17, 226-28 (1981).

31 This point is developed in R. Randall Kelso, Godel, Escher, Bach: More Darkness or Day for Night, 1981 Wis. L. Rev. 847-52. 
above, ${ }^{32}$ naturally cannot internalize this principle on their own. Moral philosophers during the $17^{\text {th }}$ $19^{\text {th }}$ century Age of Enlightenment, operating in a Newtonian world, also typically began their analysis with the assumption that rational thought was self-interested. They then either affirmed that as a principle of morality, like Hobbes and Nietzsche, or created a prism to alter that principle. This was done either by rejecting pure reason as a guide, like the moral sense philosophers of the Scottish Enlightenment, or altering an understanding of pure reason, like Immanuel Kant's principle of reason willing only that which can be made a universal law. Today, however, given an Einsteinian understanding of rationality, no prism is necessary to affirm the central principle that rational thought is not self-interested.

This principle, that rational thought is non-egocentric, combined with the assertion that moral thought should be rational, supports as moral the foundational principle of most moral traditions: the principle of love of neighbor as oneself, or equal concern and respect for others, or behave according to the logic of the impartial spectator. Moral conclusions directly derivable from this principle are also rational. These include such widely-shared moral principles such as not taking innocent life, respecting other persons' bodily integrity and personal property, and not lying to other people for one's personal gain. More generally, love of neighbor as oneself supports "liberty" of the individual self, but "equality" toward others, and thus "fraternity" with them, the phrasing used during the French Revolution.

This view naturally rejects the concept of self-interested "possessive individualism," as well as the opposite extreme of self-sacrifice or "altruism." Instead, rational thought supports the impartial spectator's view of equal concern and respect for both oneself (and thus not self-sacrifice) and others (and thus not possessive individualism). ${ }^{33}$ In modern terminology, this view supports "five faces of freedom" defined as "self-individuating liberalism" of personal development and expression, combined with "homeostatic communitarian ideals" of similar rights to development and expression in others, combined with "positive" freedoms to take part equally in government and "negative" freedom from unwarranted government restraint, and a "progressive" agenda. ${ }^{34}$ For a purely rational thinker, these "positive" and "negative" freedoms are not rights in and of themselves, and thus in conflict with the other aspects of freedom, as they might be if used unrestrained for one's selfinterested gains. Those freedoms are instead derivative of equal concern and respect, and thus must be used consistent with that principle, a view with roots in a Madisonian concept of democracy grounded in the civic republican tradition. ${ }^{35}$ This view that all these "freedoms" are consistent with one another is similar to the observation made by Pope John Paul II, discussed at Part II, Section C,

32 See supra text accompanying notes 13-18.

33 On this point regarding "possessive individualism" and "altruism," see Kelso, supra note 31 , at $852-55$.

34 See John Lawrence Hill, The Five Faces of Freedom in American Political and Constitutional Thought, 45 Boston College L. Rev. 499 (2004).

35 See John Lawrence Hill, A Third Theory of Liberty: The Evolution of our Conception of Freedom in American Constitutional Thought, 29 Hastings Const. L.Q. 115 (2002). 
that the Commandments in the second half of the Decalogue (Commandments 6-10) are not independent, but merely more detailed elaboration of the principle of love of neighbor as oneself.

It is important to note that this derivation of moral principles from "reason" alone is different than traditional natural law theories that tried to derive moral principles based on an understanding of the "nature of human beings and the world in which they live." "Focus on such a supposed "concrete human nature" is predictable for moral reasoning based more on concrete customs and traditions. However, a focus on reason will be based on the demands of rational thought alone, and will understand that while reality, and thus rational thought, is the same for all individuals, there is not a fixed "human nature" applicable to all individuals equally given each individual's unique combination of DNA. Further, while one could try to develop a theory of "adult" human nature that would reign in self-centered desires of childhood, and this author sketched the outlines of just such a theory more than 20 years ago, ${ }^{37}$ the better approach is to derive rational moral principles directly from reason, rather than arguing there is an "adult" rational human nature that should trump irrational emotions and desires. There is no fixed "human nature," and even if there were, an attempt to isolate aspects of that nature and argue that certain aspects, like advanced cognitive thought, are more human than other aspects, like baser emotions or desires, is not capable of rational justification.

The second point to be made about these previous attempts at trying to provide rational principles of moral judgment is related to this point. To be persuasive in the unnecessary resort to some moral prism in order to banish egotism from rational thought, the philosopher has to defend why that philosopher's particular prism, though going beyond the rational principle of love of neighbor as oneself, is nonetheless valid. Despite much energy devoted to this problem over centuries of philosophy, such defense of any of these particular prisms is not capable of rational justification. An example may help make the point. In ancient times, much energy was given to the problem of "squaring the circle." This meant finding a way mathematically, using fractional algebra, to construct a square, the area of which is equal to the area of a given circle. Eventually it was shown that there could be no solution to this problem, since the area inside a circle was a multiple of "pi," which is an irrational number not capable of fractional representation. ${ }^{38}$

In the $20^{\text {th }}$ century, Godel's Theorem has provided the corresponding mathematical proof of the impossibility of rationally justifying any particular moral prism. Godel's Theorem proves that no system of propositions can prove the validity of its own starting premises. Thus, no system of "moral oughts" can be proven valid based upon other "moral oughts," since those "moral oughts" are not a priori valid either. Godel's Theorem thus confirms that there is no way to make a "category" jump from an "is" to an "ought," because that violates the internal logic of the system, and there are no a priori "oughts" on which to base other "oughts" either. Therefore, despite

36 See, e.g., Randy E. Barnett, A Law Professor's Guide to Natural Law and Natural Rights, 20 Harv. J.L. \& Pub. Ply. 655, 663 (1997).

37 See R. Randall Kelso, Book Review: Reason, Morality, Wealth: Gewirth, Posner, and the University of Chicago Approach, 7 Okla. City. U.L. Rev. 131, 144-68 (1982).

38 See Morris Kline, Mathematics in Western Culture 50-51 (1970). 
elaborate attempts at appealing to "reason" or to "widely-held moral intuitions," no philosophical prism is ultimately capable of analytic defense. In short, Hume's insight from two centuries ago that there is no way to bridge the gap between "is" and "ought" is confirmed by Godel's Theorem. ${ }^{39}$

Despite the view of some to the contrary, Godel's Theorem does not prove that agreement on what thought is rational is impossible. It is possible to determine the contours of rational thought, that is, thought which conforms to physical reality, once an assumption is made that reality exists and life is not a Kafkaesque dream. Godel's Theorem does caution, however, that it is impossible to prove that rational thought is moral. The most one can say is that any moral system different than the one imposed by rational thought is necessarily irrational. Further, because of Godel's Theorem, the only moral system that rationally can be shown to transcend individual preferences, and thus which can serve as a basis for all persons to agree through informed dialogue, rather than through force (either military force, psychological conditioning, or social pressure), is the morality of rational thought. ${ }^{40}$

In sum, one can say that a rational person would follow the principle of love of neighbor as oneself, but that any other moral principles not rationally derivable from this principle are not capable of rational defense. They represent only individual preferences or desires that each individual should feel free to adopt or not, as long as those principles do not conflict with the principle of love of neighbor as oneself. This view thus mandates tolerance of other individuals' practices to the extent they do not violate the principle of love of neighbor as oneself, but intolerance of individuals who violate this principle by attempting to impose their non-rationally based moral prisms on others. This is similar to Einstein's theory of relativity, which states as a non-negotiable, absolute truth that one must give equal concern and respect to others' frames of reference in addition to one's own to give an adequate account of the physical universe. European countries, therefore, like England, France, Denmark, or the Netherlands, that are moving to express intolerance toward individuals who wish to impose their non-rationally based religious views on others, reflect this insight.

Several examples may help make all of this analysis more concrete. Some members of the Jewish religion feel very strongly in the morality of maintaining a kosher diet. Maintaining a kosher diet is part of their religious tradition - their moral prism - by which they get to the principle of love of neighbor as oneself. Because maintaining a kosher diet does not seem to be plausibly connected to the principle of love of neighbor as oneself, that principle is merely a collateral moral principle of the Jewish prism that other individuals should feel free to accept or reject. Such preference is

39 See Kelso, supra note 31, at 832 ("What Godel's theorem cautions is that it is impossible to choose between functions which go from the level of physical existence ["is"] to the level of selfreferential, metaphysical statement ["ought"].); R. M. Hare, Moral Thinking: Its Levels, Method and Point 16 (1981) ("Hume's Law ("No "ought” from an "is")), discussing David Hume, A Treatise on Human Nature (1739). For two entertaining descriptions of this problem, see Louis M. Seidman, This Essay is Brilliant/This Essay is Stupid: Positive and Negative Self-Reference in Constitutional Practice and Theory, 46 UCLA L. Rev. 501, 502-06, 538-75 (1998); Arthur Leff, Unspeakable Ethics, Unnatural Law, 1979 Duke L.J. 1229, 1249 (1979).

40 See generally Kelso, supra note 31, at 831-34. 
perfectly fine so long as no attempt is made to impose that principle of a kosher diet on others.

While this example may seem self-evident, a possibly more controversial, but analytically equivalent, example would be the attempt of some individuals to impose on other individuals what is kosher in matters of sexuality. Of course, some coercive sexual practices, like other forms of coercive behavior, will violate the principle of equal concern and respect and loving one's neighbor as oneself. Some kinds of exploitative sexual practices, even if not directly coercive, would violate this principle as well. Such practices should not be tolerated. However, despite this observation, there are a wide range of sexual practices between competent consenting adults, both heterosexual and homosexual, that do not appear to violate the principle of equal concern and respect.

John Finnis' prism, as well the prisms of many religious traditions, through which they get to the principle of love of neighbor as oneself, make immoral some of these practices. For example, Finnis has concluded that homosexual acts "on a moral analysis are always objectively wrong, like other essentially masturbatory acts" because in his view of morality a sense of "equal worth and human dignity" requires outlawing such conduct "on the ground that it expresses a serious misconception of, and actually degrades, human worth and dignity, and thus degrades their own personal worth and dignity." ${ }^{41}$ Finnis' argument, however, has been rightly criticized as being based not on a principled extension of equal concern and respect for others, but as reflecting traditionally held biases implicit in Finnis' account of basic human goods. ${ }^{42}$ To the extent that individuals succeed in imposing on others these collateral biases of their moral prisms, they are not acting in a rationally justifiable manner, and, from the perspective of reason, are not advancing the common good of society.

Of course, some persons, and some religious traditions, argue against homosexuality, or masturbation, or the use of contraceptives, based on the belief that the "purpose" of sexual activity is procreation. Thus, any sexual activity that does not carry the possibility of procreation is immoral. Unless such reasoning can be plausibly derived from the rational principle of equal concern and respect, such a view would be just another prism of moral beliefs that individuals should feel free to adopt or not. It is unclear what that plausible rational derivation would be. "Activities" do not have "purposes." Only people have purposes that people, themselves, define. If any particular individual's collateral moral belief is that sexual activity should only be for the purpose of procreation, that would be fine for that individual, but that view should not be imposed on others. This is true even if that collateral moral belief is embedded in a moral theory or religious doctrine whose foundational principle is the rational principle of love of neighbor as oneself.

With respect to this point, it is true that Aristotle's view was that objects, in addition to people, have purposes. Through acceptance of this Aristotelian notion in St. Thomas Aquinas' natural law theory, this view still forms part of much modern Catholic natural law today. Aristotle's famous example

41 John M. Finnis, Legal Enforcement of "Duties to Oneself”: Kant and Neo-Kantians, 87 Colum. L. Rev. 433, 437, 445 n.60 (1987).

42 See, e.g., David A.J. Richards, Kantian Ethics and the Harm Principle: A Reply to John Finnis, 87 Colum. L. Rev. 451, 465-71 (1987). 
of his thesis on objects was that "an acorn" has a purpose "to grow into an oak tree." Aristotle stated this as part of his thesis that every phenomena can be understood in light of four causes- material, formal, efficient, and final - including a final cause, or purpose. For Aristotle, "in the case of nonhuman nature, the final cause of things is simply its formal cause (that is, its shape, or substance, or essence)." In contrast, human beings "exercise a different kind of final causation that is directed to purposes beyond their own form or shape. ${ }^{43}$ As applied to individuals, Aristotle is right that individuals do have purposes for which they act. However, from the perspective of science, "acorns," being non-conscious entities, do not have purposes. Although some "acorns" will grow into "oaks" under the regular order of events, it represents an anthropomorphic fallacy to state that they have a purpose to do so. Pathetic or anthropomorphic fallacy has been defined as "[i]ncorrectly projecting (attributing) human emotions, feeling, intentions, thoughts, traits upon events or objects which do not possess the capacity for such qualitites." 44 Aristotle is thus wrong when concluding that the two kinds of causation, conscious and non-conscious, are similar and that events or objects have purposes.

Regarding the procreative purpose that conscious individuals may attribute to sexual activity some of the time - as opposed to the irrational view that the non-conscious activity itself has some purpose - it is nevertheless true that sometimes, between consenting adults, the purpose of sexual activity may not be procreative, but may be merely to exercise an inalienable right to "life, liberty, and the pursuit of happiness." From the perspective of reason, there is nothing immoral about that, because that activity does not appear to deny either party equal concern and respect, even if some persons may disagree with this analysis because of their customary or traditional views.

\section{The Religious Form or Shape of Rational Moral Reasoning}

As with secular reasoning about morality, religious understanding of moral principles can also been seen to reflect various kinds of moral reasoning. For example, there is a child-like understanding of the Bible as God the Father to be obediently followed or else one will be punished. There is a view where some authority figure, like the Pope, is viewed as the authoritative interpreter of the Bible, similar to the way in which the Emperor or King for secular society under the "divine right of Kings" was viewed as the authoritative interpreter of law. There is the view of the Reformation where biblical interpretations of the community of the faithful become more critical, rather than blind adherence to papal interpretations, as in the Baptist, Anabaptist, and others similar denominational traditions. Many of these denominations end up adopting very literal interpretations of the Bible as part of their interpretive traditions. Then, there is a spirit of fuller participation by the community of the faithful represented by Vatican II modernizations during the 1960s. Finally, there is Pope John Paul II's emphasis on deriving basic religious principles from reason and truth in his 1993 encyclical Veritatis Splendor (The Splendor of Truth).

43 Brian Cubbage, Aristotle 2 (www.personal.psu.edu/users/n/b/nbc104/HSAAITIA.html).

44 L. Van Warren, Thirty-Five Fallacies Explained (www.wdv.com/Writings/Stories/ TheRules/fallacy.html) (fallacy no. 35). 
Two points are important to note from Veritatis Splendor. The first point, as Pope John Paul II stated, is that the Christian natural law tradition is concerned with truth and reason, as is the Enlightenment tradition. ${ }^{45}$ It is for this reason that John Paul II supported a reconciliation between faith and reason, including drafting an explicit apology for the Church's forced recantation of Galileo's scientific insights, and indicating his belief that evolution is "more than just a hypothesis," but entitled to greater respect than that. ${ }^{46}$ The view has supported Catholic schools teaching Darwinian evolution as part of their science curriculum.

More recently, Pope Gregory XVI has supported an influential cardinal, Christoph Schonborn, questioning the accuracy of the Darwinian explanation of evolution, and supporting an alternative view, typically called Intelligent Design. Cardinal Schonbron wrote, "Evolution in the sense of common ancestry might be true, but evolution in the neo-Darwinian sense - an unguided, unplanned process of random variation and natural selection - is not. Any system of thought that denies or seeks to explain away the overwhelming evidence for design in biology is ideology, not science." ${ }^{\prime 7}$ From the perspective of reason, resolution of this issue should turn on whether in fact there is "overwhelming evidence for design in biology." To that extent, the test proposed by Cardinal Schonborn is consistent with the view of reason that science should be the ultimate determining guide. Contrary to the Cardinal's assertions, however, from the perspective of science and reason, it is unclear there is any real evidence to support Intelligent Design, much less "overwhelming evidence."

The second important point from Veritatis Splendor is the connection between the specific principles of morality stated in the Bible and the general moral command of "love of neighbor as oneself." In Veritatis Splendor, John Paul II stated:

[T] he commandments belonging to the so-called "second tablet" of the Decalogue, the summary and foundation of which is "the commandment of love of neighbor:" [In these] commandment[s] we find a precise expression of "the singular dignity of the human person," "the only creature that God has wanted for its own sake." The different commandments of the Decalogue are really only so many reflections on the one commandment about the good of the person, at the level of the many different goods which characterize his identify as a spiritual and bodily being in relationship with God. ${ }^{48}$

45 See generally Pope John Paul II, Encyclical Letter, Veritatis Splendor (The Splendor of Truth) (1993).

46 See generally Pope John Paul II, Encyclical Letter, Fides \& Ratio (The Relationship Between Faith and Reason) (1998).

47 Christoph Schonborn, Finding Design in Nature, The New York Times, Op. Ed. Page (July 7, 2005). See generally Cornella Dean \& Laurie Goodstein, Leading Cardinal Redefines Church's View on Evolution, The New York Times (July 9, 2005).

48 Veritatis Splendor (The Splendor of Truth) II 13 (Aug. 6, 1993). 
The view implicit in this passage is that one should understand biblical commandments based upon their consistency with being derivable from the background principle of "love of neighbor," and not as independent principles separate from that concept. For example, during the pre-Civil War period of American history, many religious Southerners resorted to text in the Bible to support the morality of the institution of slavery. To rebut such pro-slavery proponents' citation of independent biblical passages alleged to condone slavery, the abolitionist movement emphasized Jesus' and St. Paul's general statements concerning "love of neighbor as oneself," the equality of all persons, and the "Golden Rule" of treating one's fellow human beings as one expects to be treated by others, that is, giving them equal concern and respect.

Such use of the Golden Rule rejected a version of the Golden Rule limited by the concrete prejudices and beliefs of individuals at any one time. Moral developmental psychologists call this limited understanding of the Golden Rule, based on concrete operational thought only, the "concrete Golden Rule." ${ }^{49}$ Under this view, persons might end up with different moral principles, since those principles would be dependent on the concrete variations in how different individuals might wish in fact to be treated by others, based on any customary or traditional egocentric desires or prejudices any individual may have that would affect how they would want to be treated in practice. In contrast, the abolitionists derived moral principles more abstractly from formal operational thought and its rational understanding of the logical implications of the principle of "equality of all persons" and "love of neighbor as oneself." It is this derivation of moral principles from "love of neighbor as oneself" that is supported by Pope John Paul II in the passage from Veritatis Splendor quoted above. Under this derivation, all rational persons will agree on basic moral principles, since these principles are not dependent upon concrete variations in how different individuals might wish to be treated by others, including any egocentric desires any particular individual may have, but rather are based upon the logical implications of treating persons equally, logic being the same for all rational individuals.

When such a rational understanding of biblical passages is placed alongside a rational understanding of the Enlightenment tradition, the disparities in moral judgment between the two should collapse, as both will reject the concretely, fixed prejudices of individuals in the past. At the end of the day, a society based on reason will have the great toleration for individuals, both within any particular community and cross-community, as long as those individuals give other individuals equal concern and respect. Indeed, rational moral reasoning allows for no real difference between the two kinds of toleration, within or between communities in a society, since rights are based upon reason, not upon the customs or traditions of some groups in society.

This conclusion is a necessary corollary of the fact that these rational moral rights involve the equality of human rights and respect for the dignity of human beings as individuals, a dignity which no society, or community within society, should be permitted to infringe. Thus, customary or traditional practices that violate the dignity of human beings as individuals, such as slavery in colonial and pre-Civil War America, or female circumcision in some societies today, are inconsistent with rational moral reasoning, even if some societies would tolerate them as part of the customs or traditions of the community, or they are part of the existing rules of that society. 
Some differences between traditional Christian doctrine and progressive moral doctrine reflect both these points from Veritatis Splendor regarding truth and deriving moral principles from the principle of "love of neighbor as oneself." For example, during the Middle Ages, the traditional Christian doctrine was that charging interest on loaned money was immoral, based on the Aristotelian analysis that "money by its nature is barren." From a modern perspective, this analysis is flawed, since there is a "time value" to having money for investment purposes that supports a reasonable interest rate being charged on money loaned. ${ }^{50}$ The flawed understanding was used during the Middle Ages to support anti-Semitism against Jews who charged interest rates on money loaned. In addition, during the Middle Ages anti-Semitism was supported by reference to isolated passages in the Bible concerning the role of Jews in the death of Jesus, and the belief of Jews that Jesus is not the son of God. These customary and traditional anti-Semitic attitudes are contrary, of course, to the generic principle of "love of neighbor as oneself" as applied in a rational manner. Rational thought would not blame individual Jews today for actions taken 2000 years ago by Jews and Romans, nor would it blame Jews because their religious prism does not view Christ as the son of God, while the Catholic and Protestant religious prisms do view Christ in that way.

It is unquestionably true that individuals who view moral reasoning through the lens of customs of the community, or traditions of society in general, tend to think it moral to impose on other individuals those customary or traditional views, and think persons who do not share those views are immoral. While that view reflects adolescent peer group mentality, that view does not reflect mature, adult reasoning. For example, merely because Jews are not the majority in most communities, and they have views different on some matters than the majority of Christians, or Moslems in predominantly Islamic societies, does not make their views immoral. As long as all individuals behave in a manner consistent with the principle of "love of neighbor as oneself," any collateral view about the divinity of Christ, or any other matter, is not a matter of a moral imperative. Based on this more enlightened view regarding moral derivation of principles from "love of neighbor as oneself," John Paul II apologized in 1998 to Jews for the Catholic Church's historic attitudes and centuries of discrimination against persons of the Jewish faith, including the Catholic Church's less than vigorous role in opposing Nazi atrocities before and during the Holocaust. ${ }^{51}$

The difference between traditional Christian doctrine regarding birth control, stem-cell research, and abortion, and progressive doctrine based on reason, reflects the same dynamic at work. For example, on the issue of birth control, traditional Christian disapproval of birth control is based principally on the flawed Aristotelian analysis that "acts" have "purposes" and that the "purpose" of sexual activity is "procreation." As discussed in Part II, Section B, "acts" do not have "purposes"; people have "purposes" which people, themselves, define. Once that flawed Aristotelian analysis is rejected, there is nothing from the perspective of giving individuals equal concern and respect that prevents any individual from responsible use of birth control in the context of consensual, non-exploitative

50 See generally Paul G. Hayeck, An Economic Analysis of the Justifications for Usury Laws, 15 Ann. Rev. Banking L. 253 (1996).

51 See Commission for Religious Relations with the Jews, The Vatican, We Remember: A Reflection on the Shoah (March 17, 1998). 
sexual relationships. Thus, such views should no more be imposed on individuals who do not share those views than the view that it is moral to maintain a kosher diet should be imposed on individuals who do not share that view, as discussed in Part II, Section B. The parable of Onan in Genesis 38, who practiced coitus interruptus with his brother's widow, provides no support for the immorality of masturbation or birth control in general, because his sin was refusal to follow ancient Jewish custom and provide an "heir" for his dead brother, a custom no religious tradition supports today.

Of course, to the extent that some forms of "morning-after" birth control, or stem-cell research, or abortions rights are viewed as the destruction of individual human life, the principle of equal concern and respect for all individuals would counsel a very different approach, since individual human life would be at stake. For most forms of birth control, however, those considerations are inapposite. Customary or traditional attitudes sensibly do not view a woman's unfertilized egg or a male's sperm as individual human life. Thus, no major religious tradition requires women to try to get pregnant each month on the ground that if the woman did not try to get pregnant, and merely permitted menstruation to occur, that is the purposeful destruction of human life, or, from the Christian tradition, violates a biblical command to "be fruitful and multiply." Similarly, no major religious tradition requires men to try to implant every bit of their sperm before the life-span of that sperm dies. By the same reasoning, male vasectomies, or use of spermatocide contraceptives, pose no moral issues in terms of the destruction of individual human life.

After conception takes place, however, an issue arises when a fertilized egg, and the developing embryo and fetus, deserves to be considered individual human life. From the perspective of scientific reason, that point would be when an individual actually exists, that is, the point of viability, roughly the $24^{\text {th }}$ week of pregnancy today. As the Supreme Court noted in Roe v. Wade, "This is so because the fetus then presumably has the capability of meaningful life outside the mother's womb. State regulation protective of fetal life after viability thus has both logical and biological justifications." 52 Prior to viability, there is not biologically an individual to protect. There is only a potential individual, though a greater potentiality than in an unfertilized egg or sperm, and increasingly certain attributes of individuality as the pregnancy continues. The fact that the fetus contains human DNA is not critical under this approach, since all cells in any individual's body contain DNA, and yet each of those cells do not have any individual right to exist. Once biological integrity is established at viability, regulation of abortion is justified. As the Court acknowledged in Roe, where continuing the pregnancy after viability would compromise the mother's life or substantial health, a balance between the rights of the mother and individual fetus must be done.

For many individuals, however, the point at which individual human life deserves protection is when the "soul" enters the body. As discussed in Roe v. Wade, the traditional doctrine of the Catholic Church until the $19^{\text {th }}$ century was that the soul entered at the point of "quickening," that is when the fetus first kicked, roughly at the $16^{\text {th }}-18^{\text {th }}$ week of pregnancy. Thus, abortions after that time were viewed as immoral. ${ }^{53}$ Once scientific understanding advanced to the point where "quickening" was
52
410 U.S. 113, 164-65 (1973).
53
Id. at 141-44. 
no longer viewed as a critical point in fetal development, the modern Catholic and fundamentalist Protestant doctrine became that the soul enters at conception. Thus, any prevention of the fertilized egg from developing into a viable life, whether by use of a "morning-after" pill, or use of embryos for stem-cell research, or abortion, is viewed as the purposeful destruction of human life.

From the perspective of reason, there is no evidence to support the claim that a "soul" exists in the religious sense, much less when the soul enters. From the perspective of reason, therefore, any point chosen is ultimately arbitrary. No passages in the Bible directly address this question either. Because of this, a religious approach committed to reason would likely take the view, consistent with the reasoned secular view regarding individual life, that an "individual soul" enters the fetus once there is an "individual body" capable of functioning as an "individual" to enter, that is, at the point of viability, rather than entering at the stage of a 2-cell, or 4-cell, or 8-cell developing embryo.

Of course, it is always a tragedy if a women finds herself in a position of having an unwanted pregnancy. Ideally, through a combination of responsible sexual choices, including abstinence, where practiced, and use of effective birth control methods at other times, unwanted pregnancies would not occur. However, sometimes individuals are not always responsible, other times birth control methods fail, and sometimes the pregnancy results from coercive or exploitative sexual practices, like rape or incest. In such situations, the individual should have the option to have access to "morning-after" pills or an abortion prior to the development of individual human life at the point of viability.

It is true that some individuals who view moral reasoning through the lens of customs of the community or traditions of society think it moral to impose on other individuals their views regarding when a "soul" enters the developing fertilized egg. From the perspective of reason, that view is not as much "pro-life," as it is viewed by the individuals who hold those views, as "proslavery," trying to "enslave" women to continue pregnancies they do not want by denying them choice regarding use of "morning-after" pills or abortions, or "enslave" persons with debilitating mental diseases from being freed from those conditions through the promise of stem-cell research. It is as offensive to reason as the other aspects of traditional Christian doctrine, which was used by similar groups of fundamentalists at earlier times in American history - particularly Deep South Red State fundamentalists - to support slavery, segregation, anti-miscegenation laws, denial of equal rights for women, anti-Semitism, rejection of Darwinian evolution, and, discussed next, denial of equal rights to gays and lesbians.

\section{The Issue of Sexual Orientation as an Example of Custom and Tradition Versus Reason from Both a Secular and Religious Moral Reasoning Perspective}

One important example of the convergence of secular and religious moral reasoning doctrine from the perspective of reason involves the issue of gay rights. Like the issues of slavery, segregation, and anti-miscegenation laws discussed in Part I, properly understood the debate regarding sexual orientation is not a debate between religious and secular moral traditions, but rather a debate among traditional customary views and progressive views based upon reason, both secular and religious. In every such debate during the 2000 years of Christendom, the progressive view based upon reason has ultimately been viewed as just, even by those who originally held the traditional view. In each 
case, an important key to the triumph of the progressive view was the acknowledgment that the literal text of the Bible did not contain authoritative passages that spoke directly to the issue. This permitted a progressive interpretation of the Bible gradually to emerge that reinforced the progressive view held by most of those in the secular Enlightenment tradition.

This will likely be true for the issue of gay rights as well. Regarding the question of the literal text of the Bible, it is important to note that individuals in ancient society had no awareness of sexual orientation. For them, the term "man" meant "heterosexual man," since the ancients presumed that all individuals, no matter what their behavior, were heterosexual. It has been noted, "The Jewish and Christian scriptures say nothing whatsoever about homosexuality. Homosexuality and heterosexuality are modern concepts coined in German psychiatric practice in 1870 . . . [T] he concept of sexual orientation is totally absent in the ancient Mediterranean world."

Of course, the ancients were aware that some individuals engaged in homosexual acts. This typically occurred, however, as in ancient Greece, in the context of a married couple, with the husband also having homosexual relations with a younger boy, as with Socrates and Alcibiades, or a married woman, like the famous poet Sappho, of the island of Lesbos, enjoying the company of other woman. ${ }^{55}$ The ancients viewed these acts, therefore, as aberrations from the individual's usual pattern of heterosexual sexual activity. ${ }^{56}$ It was only in the late $19^{\text {th }}$ century, following the beginnings of the modern science of genetics, that scientists began to understand that some individuals have a naturally occurring genetic predisposition towards same-sex sexual attraction, ${ }^{57}$ and the concept of homosexual persons entered into linguistic use.

54 Rev. Dr. Robert E. Goss, Homosexuality and the Bible: The Practice of Safe Texts (www.geocities.com/ mcc_st_louis/homo).

55 See, e.g., Antares, Buggery \& Skullduggery (www.kakiseni.com/articles/reviews/ MDA1NQ) ("Socrates, himself, while married to Xantippe, had a passionate affair with an athletic and youthful male disciple named Alcibiades."); Jennifer Goodall Powers, Ancient Weddings (www.ablemedia.com/ctcweb/consortium/ancientweddings12) ("Sappho encourages girls to look forward to marriage as a happy time of life without fear. The school did not, however, necessarily suggest that the girls give up the love of other women, as shown in Sappho's own ability as a married woman to write about her love for women.").

56 See, e.g, Male Love in Ancient Greece (www.androphile.org/S/Culture/Greece) ("The term 'homosexuality' as it is used and understood today is not applicable to Greek antiquity . . . The Greek male was not only expected to marry and to raise children, but also to be available for friendship and love with worthy youths, not to the exclusion of marriage, but as its necessary complement. ... [P] [Pssion and erotic love between two adult men . . . was generally considered unusual and held up to ridicule.").

57 See, e.g., Homosexuality: Its Genetic Basis \& Evolutionary Benefit 1 (www.danaanpress. com/alib/hsex) ("homosexuality is a product of genetics, . . . evidenced, among other things, in differences in brain structure and ... responses to hormones."). 
Given these facts, it is clear that the Bible never addresses the morality of homosexuality as such, and could not, as the ancients had no concept of homosexuality to address. Because ancient linguistic use presumed that all "men" were "heterosexual," biblical passages condemning homosexual acts by "men" can only properly be understood as being addressed to practices like the Greek practice of heterosexuals engaging in homosexual conduct. As has been stated, "No doubt Paul was unaware of the distinction between sexual orientation, over which one has apparently very little choice, and sexual behavior, over which one does. He seemed to assume that those who he condemns are heterosexual, and are acting contrary to nature, 'leaving,' 'giving up,' or 'exchanging' their regular sexual orientation. . . Paul really thought that those whose behavior he condemned were 'straight,' and that they were behaving in ways that were unnatural to them." 58 Passages in the Bible, like those in Leviticus 18 which state that men shall not "have sexual relations with your kinsman's wife" nor "lie with a male as with a woman," underscore that the biblical passages were addressed to the morality of acts by men who "lied" with a woman, that is, heterosexuals. ${ }^{59}$ The most faithful reading of the Bible, thus, is that it does condemn homosexual acts when committed by heterosexuals, and well as condemning hedonism and exploitative sexual relationships, such as in the parable regarding Sodom and Gomorrah, and condemning prostitution. Nothing in the Bible, however, explicitly addresses the morality of homosexual conduct by homosexuals in the context of loving, committed, consensual relationships.

Some commentators have gone farther to suggest that the Bible does not necessarily condemn any homosexual act done between consenting, adult partners in the context of loving, committed relationships, but only condemns homosexual acts done as part of prostitution, promiscuity, seducing children, and other such acts. ${ }^{60}$ Contrary to this view, the position suggested here is that the most faithful reading of the Bible is that the Bible does condemn all homosexual acts between persons as they were understood to be by the Bible, that is, between heterosexuals, whether adult or children, consenting or not. Under this view, the Bible does condemn homosexual acts by the roughly $95 \%$ of the populace who are heterosexual. Thus, only with respect to the roughly $5 \%$ of the populace who are not heterosexual would current biblical understandings need to be changed. ${ }^{61}$

Even though the Bible states nothing explicitly about homosexuals engaging in homosexual conduct, related biblical passages support the morality of homosexuals engaging in homosexual conduct in the context of loving, committed relationships. One of the 10 Commandments states that one "shalt not bear false witness against thy neighbor." Depending on whether one is Roman Catholic or

58 Walter Wink, Homosexuality and the Bible 2 (www.glsengreensboro.org/new_page_6).

59 The passages cited here from Leviticus 18, as well as passages in Leviticus 20, and other parts of the Bible dealing with homosexual acts, are collected for easy reference at Loren L. Johns, Homosexuality and the Bible (www.ambs.edu/L.Johns/Homosexuality).

60 See Dean Worbius, The Bible and the Homosexual (www. postfun.com/pfp/homosexual).

61 See generally Support for Gay and Lesbian Equality on the Rise, NGLTF Policy Institute Study Shows 1-2 (Dec. 6, 1999) (hereinafter NGLTF Policy Study) (noting that between 4-5\% of the electorate indicated they were gay, lesbian, or bisexual in election exit polls in 1996 and 1998). 
Protestant, this may be either the $8^{\text {th }}$ or $9^{\text {th }}$ Commandment. ${ }^{62}$ The corollary to this proposition is the proposition that one shalt not lie. ${ }^{63}$ Jesus told his disciples to live in "the spirit of truth." this proposition to sexual conduct, it would be argued by those supporting gay rights that while heterosexuals should engage in heterosexual sexual conduct, homosexuals should remain true to their nature and engage in homosexual sexual conduct. Supporters of gay rights would argue that to encourage contrary behavior would be to encourage living a lie and not living in the spirit of truth.

A less controversial example, which makes the same point, involves the treatment of righthandedness and left-handedness. Just as the ancients had no accurate concept of sexual orientation, they had no accurate knowledge regarding right-handedness or left-handedness. For most of the $20^{\text {th }}$ century, it has been recognized that being left-handed is merely a naturally occurring genetic variation to which no moral significance should attach. ${ }^{65}$ To the ancients, however, the fact that less than $10 \%$ of the populace seemed to have a predisposition towards left-handedness meant that such individuals, being "not the norm," were weak and sinister, and thus targets for discrimination.

For example, it has been noted that the word "left" comes from an Old English word meaning "weak" or "worthless," and that our word "dextrous" comes from the Roman word "dexter," which in turns meant "right." The Roman word for "left" is "sinister." Prejudices against left-handers abound, "for throughout history, lefties have been considered inferior. Centuries ago, the Catholic Church declared left-handed people to be servants of the Devil. For generations, left-handers who attended Catholic schools were forced to become right-handed." ${ }^{96}$ In paintings and other art work, the devil was typically shown as holding his scepter in his left-hand, while Popes were shown as being right-handed. The left side of anything "has long been considered a bad omen, unlucky, evil and dirty. Ancient tarot cards and pictures have often portrayed a left-handed Satan."67

62 See generally Ten Commandments (www.therain.org/studies/ten) (listing different biblical versions of the Ten Commandments).

63 See The Preacher's Files, Lying Lips Are Abomination To The Lord (www.preachersfiles. com/sermon_outlines/sermonsund/lying); Psalms 101 (www.bju.edu/bible/ pas/101) ("He that worketh deceit shall not dwell within my house: he that telleth lies shall not tarry in my sight.").

64 See, e.g., Article 8-The $8^{\text {th }}$ Commandment (www.christusrex.org/www1/CDHN/eightnim) ("To follow Jesus is to live in 'the Spirit of truth,' whom the Father sends in his name and who leads 'into all the truth.' To his disciples Jesus teaches the unconditional love of truth: 'Let what you say be simply "Yes or No.",").

65 See, e.g., Parallels: A Comparison of Social Perceptions Toward Both Left-Handed and Homosexual People 8-9 (www.traceyourhand.org/cosmos/LGBTleft/left) (discussing, inter alia, the work of W. Franklin Jones, Ph.D., A Study of Handedness (1918)) (hereinafter, Parallels).

66 Left-Handedness: Curse, Blessing or Anomaly of Nature? 1-2 (www.geocities. mollyjoy'shome) (hereinafter, Lefthandedness).

67 Kathleen Saal, Lefties Have Rights, Too (www.linkshaender-beratung.de/english/Saal). 
Other religious traditions also associated left-handedness with morally suspect behavior based on the fact that left-handedness is not the norm. For example, it has been noted, "Only a few decades ago in Japan, left-handedness in a wife was sufficient grounds for divorce. . . . In Arab nations, the right hand is used to touch parts of the body above the waist, while the left hand is used for below the naval. . . Maori women weave ceremonial cloth with the right hand, because to use the left hand would profane and curse the cloth .... African tribes along the Niger river do not allow their women to prepare food with the left hand for fear of poisonous sorcery."68 While some of these views have sensible historical explanations, like the Islamic view that one should use one hand for touching above the waist and eating, while for hygienic reasons a different hand should be used for touching below the naval, particularly wiping oneself after using the restroom, which hand does which, right or left, is not a matter of moral choice. Many of these other views have no rational explanation and are based solely on the view that merely because most people are right-handed, lefthanded acts are suspect.

Today, of course, no major Christian denomination holds that being left-handed is morally suspect. Even the practice in some public and Catholic schools in the first half of the $20^{\text {th }}$ century of encouraging students to write right-handed, even if their natural tendency was to be left-handed, has fallen into non-use over the last 25 years. ${ }^{69}$ No serious biblical scholar today takes the view that the Bible, either explicitly or implicitly, holds that left-handed acts are immoral, whether writing, throwing, playing golf, tennis, bowling, or any other act. Indeed, in the 1992 Presidential election, all three major candidates, President George H.W. Bush, Governor Bill Clinton, and Ross Perot, were left-handed, and this did not provoke any religious consternation at all. Throughout history a number of "geniuses and icons" have been left-handed, including "Albert Einstein, ... Issac Newton, Joan of Arc, Ben Franklin, Mark Twain, Julius Caesar, Napoleon and Henry Ford . . . Of [43] American presidents, seven have been lefties." 70

This is true despite the existence of some "language" and "metaphors" in the Bible that could be read to support right-handedness, such as where Jesus is reported to have said discussing charitable acts that one should "not let thy left hand know what thy right hand doeth," or, regarding Judgment Day, that God "shall set the sheep on His right hand, but the goats on the left."71 One author has noted, "One can see the similarities between the evolution of social attitudes towards left-handedness and homosexuality. ... In each case, the initial set of doctors failed to find an exact cause, and instead merely hypothesized and theorized, but failed to prove anything conclusive. However, again in both cases, the respective doctors ultimately conceded that the condition is not a willful act, nor is it a

68

See Lefthandedness, supra note 66, at 1-2.

69 See, e.g., Parallels, supra note 65, at 9 (discussing attitudes in the $20^{\text {th }}$ century that "parents must do everything in their power to influence the child towards the use of the right hand. . . $[\mathrm{M}]$ any of today's left-handed adults can remember being forcibly trained to use their right-hand.").

70 Left out? (www.teenlink.com/Past/2001/October/Pride/LeftOut) (available through any standard internet search engine using the terms "left out?, geniuses, and icons").

$71 \quad$ See Left-Handedness, supra note 66, at 2. 
mental disease, and that the groups ought to be treated with respect and dignity, and ought not to be forced to 'go the other way.", 72

An additional argument sometimes used to claim homosexuality is immoral is based on a version of Kant's categorical imperative of "universalizability,"discussed at Part II, Section A, that individuals should "act only in accordance with a principle that one could will to be a universal law." Under this argument, if everyone were consistently homosexual, that would be the end of the human race, and thus being homosexual must be immoral. Of course, if everyone were a man, or everyone were a woman, that would be the end of the human race also. So that argument proves nothing. In addition, as noted at Part II, Section A, Kant's principle of universalizability is not the same as giving all individuals equal concern and respect, since the universalizability principle can be manipulated in different ways. Further, one could will as a universal law that everyone behave according to their own biological nature, and that would support the morality of gay rights anyway.

This conclusion regarding the morality of gays and lesbians engaging in homosexual relationships is independent, of course, of whether within the context of those relationships any particular gay or lesbian couple, or single gay or lesbian individual, would wish to take on the responsibilities of parenthood. Most human beings appear to have an inclination towards parenthood. Since the concept of homosexuality was unknown in the ancient world, it is not surprising that there are no explicit passages in the Bible dealing with the morality of homosexuals taking on parental responsibilities. Based on the general biblical imperatives of "love" and "the equality of all persons," that desire to take on parental responsibility should not be denied to any human being.

Under this reasoning, homosexuals taking on parental responsibilities, either through temporary engagement in heterosexual activities, sperm donation, in vitro fertilization, or adoption, should be permitted, as long as that behavior is consistent with other moral principles, including concern for "the best interest of the child." For most children, the best environment is to have loving parents, knowledgeable enough to challenge their developing intellects, with sufficient economic means to give them a rich environment in which to grow up. While some conservative groups have alleged that gays and lesbians cannot be good parents, and it cannot be in the best interest of the child to be raised in such a household, there is no sound evidence to support that assertion, and most mainstream organizations support gay adoptions and gay parentage for those gays wishing to be parents. ${ }^{73}$ The argument that societal prejudices against such arrangements should be taken into account in determining the "best interest of the child" was properly rejected by the Supreme Court in the context of prejudice against interracial marriages in Palmore v. Sidoti, the Court noting, "Private biases may be outside the reach of the law, but the law cannot, directly or indirectly, give them effect." 74

72 See, e.g., Parallels, supra note 65, at 10-11.

73 See, e.g., Pediatric Group Endorses Gay Adoptions (Feb. 4, 2002) (www.cnn.com/2002/ Health/04/04/gay.adoption.ap/index).

74466 U.S. 429, 433 (1984). 
A number of Protestant denominations have already revised their understandings on the morality of homosexuals engaging in homosexual sexual activity, while other Protestant denominations are involved in a process of revisiting their views on the morality of loving, committed, homosexual relationships. ${ }^{75}$ The greater administrative inertia associated with the Catholic church may mean that the Catholic church will be the last denomination to revise formally their doctrine regarding homosexuality, just as the Catholic church has lagged regarding their views on celibacy and the ordination of women. As this change comes about, from the religious natural law perspective, Jesus' message of love and respect for all of God's creations - whether man or women; white, black, brown, yellow, or red; right-handed, left-handed, or ambidextrous; straight, gay, bisexual, or transgendered; disabled or not - will be actualized better on earth. Even though the Catholic Church disagreed at the time, it is apparent today that Galileo was doing God's work in the $17^{\text {th }}$ century. Despite opposition from many practicing Christians at the time, particularly in the South, it is apparent that the abolitionists in $19^{\text {th }}$-century America were doing God's work in opposing slavery, as were the Lovings when they challenged Virginia's anti-miscegenation law during the 1960s. By the same token, from the perspective of reason, supporters of gay rights are doing God's work today.

In short, a understanding of this issue from the perspective of reason would adopt the view that Jesus supported the equal dignity of all human beings, and would not adopt the prejudice against homosexuals that is part of most societies' earlier reliance on customs or traditions. This understanding of moral reasoning is consistent with the message of John Paul II in Veritatis Splendor, discussed at Part II, Section C. This is true even though on the particular issue of gay rights, like on the issues of birth control, stem-cell research, and abortion, John Paul II personally adopted a view based upon reliance on concrete customs and traditions.

In this regard it is instructive to compare the majority and dissenting opinions in the 2003 Supreme Court decision in Lawrence $v$. Texas. Adopting an understanding of the term "liberty" in the $14^{\text {th }}$ Amendment based on reason, and its principle of equal concern and respect, Justice Kennedy wrote for the majority, "These references show an emerging awareness that liberty gives substantial protection to adult persons in deciding how to conduct their private lives in matters pertaining to sex. ... When homosexual conduct is made criminal by the law of the State, that declaration in and of itself is an invitation to subject homosexual persons to discrimination both in the public and private spheres.... [This] demeans the lives of homosexual persons." ${ }^{, 76}$ Focusing on customs and traditions

75 See, e.g,., Chris Glaser, The Gay and Lesbian Religious Movement in America 2 (www. outspirit.org/contributors/glaser.movement.php) ("[T]he Union of American Hebrew Congregations (UAHC), the Unitarian Universalist Association and the United Church of Christ permit gay clergy. Of these, the UAHC and the UCC have both accepted the membership of gay congregations. The Episcopal Church . . . has a form of government that permits local bishops to make the choice."); Gay Rights Protesters Arrested in Cleveland (May 10, 2000) (www.datalounge.com/datalounge/ news/record.html?record= 7084) ("Delegates to the [United Methodist's] gathering . . . appeared ready to affirm the official stand that 'the practice of homosexuality' is 'incompatible with Christian teaching.' The Presbyterian and the Episcopal churches will also be taking on these questions.").

76539 U.S. 558, 572, 575 (2003) (Kennedy, J., opinion for the Court). 
of American society, Justice Scalia said for the dissent, “[A]n 'emerging awareness' is by definition not 'deeply rooted in this Nation's history and tradition[s].' . . Many Americans [still] do not want persons who openly engage in homosexual conduct as partners in their business, as scoutmasters for their children, as teachers in their children's schools, or a boarders in their home. They view this as protecting themselves and their families from a lifestyle that they believe to be immoral."77

In general, under the Supreme Court's substantive due process doctrine, there are two branches to determining what rights are part of the substantive due process liberty analysis. As stated by Chief Justice Rehnquist in Washington v. Glucksburg, those two branches are "those personal activities and decisions that this Court has identified as so deeply rooted in our history and traditions, or so fundamental to our concept of constitutionally ordered liberty, that they are protected by the Fourteenth Amendment." 78 A judge focused more on customs and traditions would naturally focus on the first branch of this analysis, those activities deeply rooted in our "history and traditions."

This is represented by Justice Scalia's dissent in Lawrence v. Texas. From this perspective, moral reasoning is based on the concrete customs and traditions of society. Because such moral reasoning is not based on more advanced formal operational thought, and its abstract reasoning ability to make "judgments about judgments," there is no way from the perspective of concrete operational thought from which to criticize the morality of any concrete custom or tradition. Customs and traditions are moral merely because they are customs and traditions, and if customs and traditions are deemed not sufficient by themselves to justify the morality of action, then there are no moral restraints whatsoever. As Justice Scalia stated in Lawrence v. Texas, "State laws against bigamy, same-sex marriage, adult incest, prostitution, masturbation, adultery, fornication, bestiality, and obscenity are likewise sustainable only in light of Bowers' validation of laws based on moral choices. Every single one of these laws is called into question by today's decision." 79

Moral reasoning based on adult formal operational thought is able to make "judgments about judgments." Even Justice Holmes noted in 1897, "It is revolting to have no better reason for a rule of law than that so it was laid down in the time of Henry IV." 80 For Holmes, however, even though customs and traditions are not necessarily moral, the role of the judge is to defer to the dominant forces in society, Hobbes" "Leviathan." 81 Thus, to the extent customs and traditions of society are reflected in legislation and executive enforcement, judges should defer to those customs and traditions until the democratic process moves society in a more morally enlightened direction. For this reason, a judge following Holmes' approach to judicial decisionmaking, like Chief Justice Rehnquist, would be predicted to join Justice Scalia's dissent in Lawrence v. Texas, as he did.

77 Id. at 598, 602 (Scalia, J., joined by Rehnquist, C.J. and Thomas, J., dissenting).

78

79

80

81

521 U.S. 702, 727 (1997).

539 U.S. at 590 (Scalia, J., joined by Rehnquist, C.J., and Thomas, J., dissenting).

Oliver Wendell Holmes, Jr., The Path of the Law, 10 Harv. L. Rev. 457, 469 (1897).

See Ben W. Palmer, Holmes, Hobbes, and Hitler, 31 A.B.A.J. 569 (1945). 
From the perspective of reason, however, the demands of rational thought and giving each individual equal concern and respect can be used to critique the morality of various societal customs and traditions. Such reasoning focuses on the second branch of substantive due process analysis, whether a right is "fundamental to our concept of constitutionally ordered liberty." Under such an analysis, judges can take background moral principles lying behind constitutional provisions into account when rendering decisions. One of these background principles of liberty, as stated by Justice Harlan in his influential dissent in Poe v. Ullman, ${ }^{82}$ is that arbitrary coercion is wrong. This applies to coercive sexual practices, as well as exploitative sexual practices, even if not directly coercive.

These kinds of principles make it possible to draw distinctions among Justice Scalia's "parade of horribles" listed above. Bestiality can be prohibited as there can be no meaningful consent given by animals. Such acts are thus inevitably exploitative. Prostitution or obscene speech that "lacks serious literary, artistic, political, or scientific value" 83 also raise clear issues of exploitative sexual activity. Bigamy raises issues of whether one can give equal concern and respect to multiple spouses, particularly given the historical practice of exploitation of women that has often accompanied societies permitting men to have multiple wives. Concerns with the possibility of inevitable exploitation of deep emotions built up between family members suggest consent could never be truly non-exploitative in the context of adult incest. Further, as a matter of "history and tradition," the first branch of substantive due process analysis, the legislative practice of virtually every state banning bestiality, prostitution, bigamy, and incest is different than only 13 states banning sodomy at the time of the Court's decision in Lawrence.

On the other hand, it may well be true that from the perspective of reason any attempt to regulate masturbation or fornication would raise difficult problems of justification. Even with respect to adultery, while adulterous conduct in most circumstances would violate the principle of giving one's spouse equal concern and respect - though it would be different if both parties knowingly and voluntarily agreed to have an "open marriage" - the question would arise whether this morality is a matter for state regulation or for private individual response, such as filing for divorce. With respect to the "history and tradition" branch of substantive due process, few states have criminal laws against adultery still on their books, only a dozen or so states still have civil actions for alienation of affection, and these laws are almost never enforced, with very modest penalties when enforced.

With regard to the issue of same-sex marriage, in 2003 the Massachusetts Supreme Judicial Court ruled 4-3 in Goodridge v. Department of Public Health ${ }^{84}$ that gay and lesbian couples must be given equal rights to marry under the Massachusetts Constitution's Equal Protection Clause. This holding reflects an understanding of equal protection based upon reason, rather than equal protection defined by the concrete practices and prejudices of society. Judges who believe in a static Constitution that would enshrine in constitutional doctrine traditional views at the time of enactment, and Holmesian

367 U.S. 497, 542-44 (1961) (Harlan, J., dissenting).

83

Miller v. California, 413 U.S. 15, 24 (1973).

84

798 N.E.2d 941, 949 (Mass. 2003). 
judges, with a predisposition to defer to legislative and executive action, would predictably dissent from such a ruling. For other judges, however, the question faced in the case would be whether the rational moral understanding of equality, which supports the decision, has become sufficiently embedded in background moral principles in Massachusetts that judges can rely upon it in interpreting the Massachusetts Constitution's equal protection provision, even though the decision would not be supported by the specific historical intent of the framers and ratifiers of the Massachusetts Constitution or the core holdings of Massachusetts precedent.

As American society is just in the process of evolving toward a more general moral commitment to reason and equal concern and respect, this would be a difficult call if applied to America generally. The precise question in Goodridge, of course, involved evolution within Massachusetts and the moral principles applicable to their state Constitution. As Massachusetts is among the more progressive states in the Nation, it is possible, though not certain, that the majority got the balance right. Of course, if the legislature and citizens in Massachusetts vote to amend the Massachusetts Constitution to enshrine the traditional view rejecting the concept of gay marriage, then it will be clear that the majority in Goodridge got the background moral principles in Massachusetts wrong at the current time. It appears, however, such amendment will not happen. In the fullness of time, the progressive view would likely prevail anyway, as it will for each issue discussed in this Part, and as it already has on issues such as slavery, segregation, and anti-miscegenation laws.

\section{Reason as a Motivating Factor in American Constitutional Law}

The Constitution's text grants Congress sufficient legislative power that in regulating commerce or in spending for the general welfare Congress can seek directly to implement moral reasoning on most issues of human rights. Of course, given the recent cases of United States v. Lopez ${ }^{85}$ and United States v. Morrison, ${ }^{86}$ Congress may not regulate non-economic criminal or non-economic civil rights conduct under the Commerce Clause. Since Congress has no generic criminal or civil rights power, Congress is limited in this area unless the legislative power is tied to some other enumerated power in Article I, $\S 8$, like the spending power, or the power to deal with mail fraud under the Post Office power, or patent infringement under the Patent and Copyright power, or tied to some other power outside of Article I, $\S 8$, like the $13^{\text {th }}$ Amendment power to ban slavery and involuntary servitude, or the $14^{\text {th }}$ Amendment power to ban states from violating individuals' privileges or immunities, equal protection, and due process rights.

The Constitution does not expressly grant any general power to the judiciary to impose moral notions on society, and the Court has never claimed even an implied power to proceed entirely on the basis of moral principles alone. Indeed, the Court has not built on the one provision in the Constitution that most clearly could be used for that purpose, the Ninth Amendment. The Ninth Amendment provides, "The enumeration in the Constitution of certain rights shall not be construed to deny or disparage others retailed by the people."

85

86

529 U.S. 598, 617-18 (2000). 
The judicial reasoning coming closest to using the Ninth Amendment as a basis for restraining government in the name of moral principles occurred in Justice Goldberg's concurring opinion in Griswoldv. Connecticut. Joined by Chief Justice Warren and Justice Brennan, he wrote, "The Ninth Amendment to the Constitution may be regarded by some as a recent discovery but since 1791 it has been a basic part of the Constitution which we are sworn to uphold. To hold that a right so basic and fundamental and so deep-rooted in our society as the right of privacy in marriage may be infringed because that right is not guaranteed in so many words by the first eight amendments to the Constitution is to ignore the Ninth Amendment and to give it no effect whatsoever." 87

Justice Goldberg suggested a general test for determining when an alleged human right should be considered protected by the Ninth Amendment. He said, "The entire fabric of the Constitution and the purposes that clearly underlie its specific guarantees demonstrate that the rights to marital privacy and to marry and raise a family are of similar order and magnitude as the fundamental rights specifically protected." 88 This "similar order and magnitude" test might have been used by the Court to protect a number of alleged rights. In fact, the Court has not used the Ninth Amendment as a source of alleged rights in this way.

Courts have adopted, however, Justice Goldberg's alternative characterization of the Ninth Amendment in Griswold v. Connecticut. As an alternative way of thinking about the Ninth Amendment, Justice Goldberg stated, "In sum, the Ninth Amendment simply lends strong support to the view that the 'liberty' protected by the Fifth and Fourteenth Amendments from infringement by the Federal Government or the States is not restricted to rights specifically mentioned in the first eight amendments." 89 This rationale supports the Supreme Court's development of that branch of substantive due process doctrine dealing with so-called "unenumerated fundamental rights." Under this approach, new fundamental rights can be identified if they are of "similar order and magnitude" to fundamental rights already acknowledged in Supreme Court precedents. For example, in 1942, in Skinner v. Oklahoma,${ }^{90}$ the Court held that there was a fundamental right to procreate, just as there was a fundamental right to marry acknowledged in the 1923 case of Meyer v. Nebraska, ${ }^{91}$ because both " $[\mathrm{m}]$ arriage and procreation are fundamental to the very existence and survival of the race."

A more recent example of the Court struggling with whether to create a new fundamental right based on such reasoning occurred in 1997 in Washington v. Glucksberg. ${ }^{92}$ In Compassion in Dying v. State of Washington, the $9^{\text {th }}$ Circuit Court of Appeals had held that there was a constitutional right to

Id. at 495 .

Id. at 493.

90

Skinner v. Oklahoma, 316 U.S. 535, 541 (1942).

91

Meyer v. Nebraska, 262 U.S. 390, 399 (1923).

92

521 U.S. 702 (1997). 
physician-assisted suicide, reasoning that such a right was "similar" to the fundamental rights discussed in Planned Parenthood v. Casey, based on Casey's language that at "the heart of liberty is the right to define one's own concept of existence, of meaning, of the universe, and of the mystery of human life." "93 The Supreme Court reversed, stating that any such "similarity" was not sufficient to recognize such a new constitutional right in this case.

The Court noted in Glucksburg that no text, context, or history of the $14^{\text {th }}$ Amendment supported a right to physician-assisted suicide, and that legislative and executive practice in 49 of the 50 States, with the exception of Oregon, rejected such a right. ${ }^{94}$ Even general social practices in other Western industrialized countries, with rare exceptions, refused to grant such a right. ${ }^{95}$ As Justice Stevens noted in his concurrence in the case, prudential considerations also do not clearly support such a right because the "value to others of a person's life is far too precious to allow the individual to claim a constitutional entitlement to complete autonomy in making a decision to end that life."96 With respect to Casey's broad definition of liberty, which could be used as a springboard for moral reasoning to expand the list of rights deemed to fall under the right of privacy branch of substantive due process liberty analysis, Chief Justice Rehnquist said of the Casey definition of liberty:

By choosing this language, the Court's opinion in Casey described, in a general way and in light of our prior cases, those personal activities and decisions that this Court has identified as so deeply rooted in our history and traditions, or so fundamental to our concept of constitutionally ordered liberty, that they are protected by the Fourteenth Amendment . . . That many of the rights and liberties protected by the Due Process Clause sound in personal autonomy does not warrant the sweeping conclusion that any and all important, intimate, and personal decisions are so protected. ${ }^{97}$

Thus, in Glucksburg, the other sources of constitutional interpretation - text, context, history, practice, and prudential considerations, as well as the core holdings of precedent which had never supported such a right to physician-assisted suicide - were more weighty than any general reasoning about moral rights based upon the Casey precedent's "heart of liberty" language.

The Court has recently used aspects of moral reasoning in another way in their decisions. Historically, reflecting a view of moral reasoning that rights derive from community or system-wide customs and traditions, the Court deferred to such customs and traditions in determining whether any particular governmental interests were legitimate. For example, in Plessy v. Ferguson, the Court

9379 F.3d 790, 813-14 (9 ${ }^{\text {th }}$ Cir. 1996) (en banc opinion), quoting Casey, 505 U.S. 833, 851 (1992) (joint opinion of O'Connor, Kennedy \& Souter, JJ.).

94

95

96

97

521 U.S. at 710-18.

Id. at 718 n.16, 734-35.

Id. at 741 (Stevens, J., concurring in the judgment).

Id. at 727 . 
noted, "In determining the question of reasonableness, it [the state] is at liberty to act with reference to the established usages, customs, and traditions of the people."98 In modern times, however, focused more on equal concern and respect for all individuals, the Court has been willing to call illegitimate some governmental interests that are based on societal customs or traditions where those customs or traditions reflect irrational prejudice or irrational stereotypical thinking about individuals.

For example, in applying rational basis scrutiny under the Equal Protection Clause, the Court held in 1973 that prejudice against "hippies" and "hippie communes" was illegitimate. ${ }^{99}$ In 1984, the Court held that prejudice against interracial marriage was illegitimate. ${ }^{100}$ In 1985 , the Court held that prejudice against the mentally impaired was illegitimate. ${ }^{101}$ Finally, in 1996, the Court held that animus toward homosexuals as a group was illegitimate. ${ }^{102}$ In this latter case, Romer v. Evans, Justice Kennedy quoted language from the 1973 case, United States Department of Agriculture $v$. Moreno, saying: "[I]f the constitutional concept of 'equal protection of the laws' means anything, it must at the very least mean that a bare . . desire to harm a politically unpopular group cannot constitute a legitimate governmental interest." 103 In Lawrence v. Texas, Justice Kennedy made it clear that the recognition in constitutional law of principles based upon moral reasoning may change over time our understanding of the Constitution, when he noted, "As the Constitution endures, persons in every generation can invoke its principles in their own search for greater freedom." 104

In deciding in individual cases whether to rule unconstitutional some custom and tradition, based on its inconsistency with respect for a reasoned understanding of liberty or equality, the Court has balanced arguments of historical customs and legislative and executive traditions with a reasoned elaboration of precedent. The Court's experience with societal resistance after 1954 to implementing Brown v. Board of Education ${ }^{105}$ has cautioned the Court not to get too far out in front of society in implementing moral notions. In America, it has typically been the "Blue States"of the North and West Coast that are closer to the moral reasoning of equal respect and concern for all individuals. The "Western, Plains, and Midwest Red States" are typically next in line, and the "Deep South Red States" usually have the strongest affinity for traditional and customary prejudices.

$98 \quad 163$ U.S. 537, 550 (1896).

99 United States Dep't of Agriculture v. Moreno, 413 U.S. 528, 534 (1973).

100 Palmore v. Sidoti, 466 U.S. 429, 433 (1984).

101 City of Cleburne v. Cleburne Living Center, Inc., 473 U.S. 432, 448 (1985).

102 Romer v. Evans, 517 U.S. 620, 634-35 (1996).

103 Id. at 634, quoting Moreno, 413 U.S. 528, 534 (1973).

104 Lawrence v. Texas, 539 U.S. 558, 578-79 (2003).

105 See generally Charles F. Sabel \& William H. Simon, Destabilization Rights: How Public Law Litigation Succeeds, 117 Harv. L. Rev. 1015 (2004). 
For example, the Blue States never had laws against anti-miscegenation. The Midwest, Plains, and Western Red States got rid of their laws between 1930-1960. The laws of the Deep South Red States against miscegenation had to be ruled unconstitutional by the Supreme Court in $1967 .{ }^{106}$ The Deep South Red States refused in mass to ratify the Equal Rights Amendment, along with Arizona, Nevada, and Utah. Thus, the Court created intermediate scrutiny for gender discrimination on its own during the 1970s. ${ }^{107}$ Although all states had laws against sodomy in 1960, only 24 states had such laws in 1986, and there were only 13 states, predominantly Deep South Red States, that still had such laws in 2003 when the Court ruled them unconstitutional. ${ }^{108}$ It was only when less than 20 states, a majority of those in the Deep South, still applied the death penalty to mentally retarded individuals and/or juveniles that the Supreme Court ruled those unconstitutional after 2000. ${ }^{109}$

The experience with slavery before the Civil War, and the experience with segregation after the Civil War until Brown v. Board of Education, suggests that waiting for the customs and traditions of states to evolve on their own absent imposition is not a strategy for success. Individuals who do not think in moral terms based on reason, but rather based on customs and traditions, cannot be reasoned with by definition. Metaphorically, one can talk with such individuals until one is literally "Blue in the face" and they will stay with their "Red State" traditions. In contrast, if one imposes a new custom and tradition on those states, a generation or so later the new custom and tradition will be accepted by most individuals whose morality is determined by customs and traditions.

This has occurred in the United States either by military occupation, as after the Civil War with respect to slavery, or by Supreme Court decisions since 1954, with respect to segregation, antimiscegenation laws, access to contraception, and equal rights for women. Whether the issues of abortion rights and issues of equal civil rights for gays and lesbians will become accepted at the current time, or whether on those issues the Court had gotten too far out in front of American society, remains to be determined. In the fullness of time, however, the moral vision of equal concern and respect is likely to be represented by the law in American society, just as it is increasingly the dominant moral vision in Western Europe and Canada. Hard-right conservative parties, as the Tory Party became under Margaret Thatcher in England, or Jean-Marie Le Pen and his National Front Party in France, have little chance of long-term electoral success in societies with an educated populace. Only by adopting a more moderate stance, such as advanced by David Cameron in Britain, or Stephen Harper in Canada, do those parties stand chances of electoral success.

Of course, since those "Red State" individuals' commitment to equal concern and respect is not based on actual commitment to adult reason, but based on newly-imposed customs and traditions, their commitment is not as likely to be as vigorous or complete an acceptance of those moral notions

106 Loving v. Virginia, 388 U.S. 1 (1967).

107 Craig v. Boren, 429 U.S. 190 (1976).

108 Lawrence v. Texas, 539 U.S. 558, 578-79 (2003).

109 Roper v. Simmons, 125 S. Ct. 1183 (2005) (death penalty as applied to juveniles); Atkins v. Virginia, 536 U.S. 304 (2002) (death penalty as applied to mentally retarded individuals). 
as individuals who reason from the perspective of adult reason. But the acceptance may be good enough. For example, many conservative Southerners in the 1920s would have opposed Clarence Thomas for wishing to marry a person of a different race, and their laws before 1967 would have made it illegal for Justice Thomas to live with a white wife in Virginia. A generation or so after the Supreme Court declared Virginia's anti-miscegenation law unconstitutional on both equal protection and due process grounds in Loving $v$. Virginia ${ }^{110}$ Justice Thomas is one of the favorite Justices among Southern conservatives and is able to live comfortably in Virginia despite his being in an interracial marriage. Similarly, the issue of gay marriage may not be as controversial a social issue as it is today a generation or so after it becomes more prevalent, based on court decisions declaring prejudice against gays and lesbians a violation of equal protection and/or due process.

Of course, not every individual in a Blue State reasons from the perspective of adult reason, and not every individual in a Deep South Red State reasons from the perspective of customs or traditions only. In addition, it is unquestionably true that some individuals who are cognitively bright do not apply the higher level of cognitive reasoning to moral tasks. This can be because of a refusal to adopt advanced cognitive reasoning and its principle of "equal concern and respect" based on "love of neighbor as oneself" as a guide, instead basing moral judgments on custom and tradition (perhaps William Bennett?), or self-interested possessive individualism (perhaps Vice-President Cheney?); or an unthinking adherence to traditional attitudes by not considering the demands of advanced cognitive reasoning (perhaps Justice Thomas?), sometimes accompanied by blind adherence to traditional religious elaboration of "love of neighbor as oneself" that cannot be defended based on a reasoned elaboration of that principle (perhaps President George W. Bush?); or a pathological rejection of reason in favor of blind adherence to custom and tradition (perhaps Justice Scalia in Lawrence v. Texas?); or just a sinister decision to behave less morally (perhaps Karl Rove?). For young children who do not have the capacity yet for formal operational thought, and thus have the "original sin" of being self-centered as an initial matter, or for older children whose educational progress is more limited because of genetic, social, or lack of individual effort factors, reasoning at lower levels of moral reasoning would be the best they can do until increased educational success brings such individuals along into more advanced stages of cognitive reasoning.

Historically stronger educational systems in the North have generally meant that a larger percentage of individuals in those states reason at the higher level of moral reasoning. Therefore, the customs and traditions of those states better reflect that level of moral reasoning. Thus, even individuals reasoning in Blue States at the level of customs and traditions tend to follow customs and traditions reflecting progressive reason. Similarly, progressive religious traditions can help individuals who reason in terms of childish self-interest or adolescent peer group customs and traditions to adopt views consistent with an adult reasoned elaboration of the principle of "love of neighbor as thyself," that is give each individual equal concern and respect, based upon the self-interest of a Judgment Day judged by progressive values, or supporting progressive customs and traditions.

In contrast, the customs and traditions in the Deep South Red States tend to reflect more traditional attitudes based on an inadequate embrace of scientific truths and inadequate taking other persons'

110

Loving v. Virginia, 388 U.S. 1 (1967). 
perspectives into account. It is those customs and traditions - "that old-time religion" that is "good enough for me," as the song states - that needs changing from the perspective of adult reason. Historically, such attitudes were prevalent among the Dixiecrat wing of the Democratic Party. Today, based upon the long-term results of President Nixon's "Southern strategy" of the 1960s and 1970s, these attitudes dominate the modern Republican Party, with the Republican Party the majority party in Congress because it includes not only this perspective, but also sufficient numbers of fiscally conservative, but socially liberal legislators elected from "Blue States." These legislators, who represent more equal concern and respect values, are connected to the older Republican Party that had a stronger "East Coast Establishment" or "Rockefeller Republican" wing. While a larger number of Dixiecrat Democrats have left the Democratic Party over the past 40 years, only a few such Republicans, such as Senator Jim Jeffords of Vermont, have left the Republican Party. Thus, the Republican Party has the "bigger tent" today. To the extent the Republican Party commits more completely to the traditional "Dixiecrat" view of social policy based on traditional customs and traditions, more "Rockefeller Republicans," who hold more progressive values based on reason, may choose to vote Democratic, returning the parties to more equal competitive balance.

In the long run, the more cognitively advanced kind of moral reasoning is likely to prevail in America, just as it is tending to prevail in Western European countries and Canada. Over time, the demands of logic and rational thought have tended to drive societies with stronger educational systems. For societies with weaker educational systems, like those in Africa and the Middle East, evolution towards democracies based on reason will be more problematic.

In the American experience, it is no surprise that those states with historically stronger educational systems have typically adopted higher levels of moral reasoning at any particular time. For example, it has been noted about the $19^{\text {th }}$ century in America, "Despite the controversy over enacting constitutional provisions and legislative statutes requiring individuals to pay taxes to support a public school system, public support for state-operated schools was gradually obtained. This process began with the New England states in the first few decades of the nineteenth century, spread to the mid-Atlantic and mid-western states in the decades preceding the Civil War, and finally, came to the southern states in the war's aftermath."111 Even after the Civil War, of course, the economic consequences of that War on the South resulted in educational systems that lagged behind the North for many decades. This educational disparity explains, in part, the South's stronger embrace of customary or traditional reasoning that supported slavery, segregation, anti-miscegenation laws, antiSemitism, and a greater reluctance to embrace Darwinian evolution. It has also meant that overcoming these attitudes has been more difficult in the South because of these customs and traditions, which often have been reinforced by traditional religious schooling and indoctrination, despite their inconsistency with reasoned elaboration of "love of neighbor as oneself."

Of course, it is important to note that many of these individuals have "a good heart." It is nonetheless true that throughout human history individuals with "good hearts" have nonetheless embraced doctrines that are not moral from the perspective of giving individuals equal concern and

111 John Dinan, The State Constitutional Tradition and the Formation of Virtuous Citizens, 72 Temp. L. Rev. 619, 640 (1999). 
respect. At the time, such individuals may believe they are behaving morally, and if religious, may believe they are doing God's work. From the perspective of reason, however, that would not be true. Actions are ultimately what count, not intent. From a reasoned understanding of the Bible, the message of Christ is not that having a "good heart" is enough to be a "good person." The relevant biblical passages are "by their fruits, you shall know them" and "the truth shall set you free."

Of course, there are no doubt some individuals whose weaker educational level, and thus less cognitively advanced moral reasoning, reflects not adolescent peer group mentality, but reasoning based upon the self-interest of childish egocentricism, discussed in Part II, Section A. For a number of such minority individuals, the choice in voting would be between a Republican Party dominated today by customs and traditions of whites living in "Red States," or support for a Democratic Party whose ideals reflect embrace of diversity and support for equal concern and respect. Given that choice, their natural self-interest is to vote Democratic. For many minorities focused on the customs and traditions of their communities, protecting those customs and traditions may also suggest voting for a Democratic Party more willing to embrace diversity and belief in equal concern and respect.

For a number of whites operating at the level of childish, self-interest, their economic self-interest may lie with the Democratic Party, but their views on social issues may be more consistent with the customs and traditions of whites living in "Red States." Indeed, to the extent they view the Democratic Party as pandering too much to the economic self-interest of minority voters, through forms of welfare, affirmative action, and other such programs, they may view their economic selfinterest as connected more to the Republican Party as well. Further, to the extent that such whites live in rural or suburban communities, without the direct, day-to-day, concrete experience of dealing with the diversity of large city life, it is easier for such individuals to settle in their moral reasoning into the comfort of their community values (what can be called their "nice little lives"), without having to deal with, or respond equitably to, the reality of diversity that might push their moral reasoning toward embrace of diversity and giving each individual equal concern and respect.

At the end of the day, no matter what mechanism suggests to individuals at various levels of moral reasoning which political party to support, the perspective of reason would look to the actual policies adopted by any political party. In doing this, one has to look beyond slogans. For example, the French Revolution was carried out against the backdrop of the slogan "liberty, equality, fraternity," which reflects, as a slogan, equal concern and respect, as noted in Part II, Section B. However, in practice, the French Revolution was a failed attempt to replace a Monarchy with a fledgling democracy, which fell back into the Dictatorship of Napoleon. The French Revolution did not yield a modern society truly committed to equal concern and respect for all citizens in the mold of emerging Western European societies today. Given the general level of education at the time, it should not have been a surprise that the predominant motive of the Jacobins in the streets was their own childish self-interest, not the adult principle of equal concern and respect for all.

It is important to note that use of rational thought to advance moral concepts through the Due Process Clause, Equal Protection Clause, and others Clauses in the Constitution is consistent with an "original intent" approach to constitutional interpretation. Certainly many of the framers and ratifiers viewed moral duties toward society in light of Adam Smith's principle of the "impartial spectator" and the Scottish Enlightenment's related view of duties of "sympathy" toward one's 
fellow citizens. ${ }^{12}$ The Declaration of Independence phrased "unalienable" rights as rights to "life, liberty, and the pursuit of happiness," reflecting the "moral sense" of the Scottish Enlightenment of Frances Hutcheson, David Hume, and Adam Smith. ${ }^{113}$ The Scottish Enlightenment was closer in this manner to the civic Republican tradition, and the French Enlightenment's phrasing of "liberty, equality, and fraternity." The Due Process Clause of the Fifth Amendment, of course, adopted the Lockean concept that no person may be deprived of "life, liberty, or property without due process of law." 114 This phrasing was also used in the $14^{\text {th }}$ Amendment. However, as stated in 1923 in Meyer $v$. Nebraska, one of the foundational cases for modern $14^{\text {th }}$ Amendment substantive due process doctrine, "liberty" includes "those privileges long recognized at common law as essential to the orderly pursuit of happiness by free men," $" 15$ the Scottish Enlightenment phrasing.

In general, the civic Republican tradition focused on the role of government to help promote civic virtue in society, rather than promoting the childish self-interest of members of society. ${ }^{116}$ Professor Mark Tushnet has noted:

The [classic] liberal tradition stresses the self-interested motivations of individuals [sometimes called possessive individualism] and treats the collective good as the aggregation of what individuals choose .... Although it acknowledges the role of public institutions in providing the framework for individual development, the liberal tradition insists that such institutions be neutral toward competing conceptions of the good and tends to emphasize the risks of governmental overreaching. The republican tradition, seeing public institutions as important means by which private character is shaped, is less suspicious of government. . . .

[Republicans] understood that people would sometimes heed the call of self-interest rather than of public interest. They were therefore intensely worried about what they called corruption, the use of public offices for private interest.... They argued that alterations in institutional design can constrain corruption directly, by limiting opportunities in which self-interest can overcome civic-mindedness, and indirectly, by reinforcing the citizenry's dedication to the public interest.

112 See generally Robert G. Natelson, A Reminder: The Constitutional Values of Sympathy and Independence, 91 Ky. L.J. 353, 358-82 (2003); Robert G. Natelson, Federal Land Retention and the Constitution's Property Clause: The Original Understanding, 76 U. Colo. L. Rev. 327, 336-40 (2005).

113 See generally Garry Wills, Inventing America: Jefferson's Declaration of Independence (1978); Garry Wills, Explaining America: The Federalist (1981).

114 U.S. Const. Amend. V.

115262 U.S. 390, 399 (1923), interpreting U.S. Const. Amend. XIV.

116 See generally Symposium on Classic Philosophy and the American Constitutional Order, 66 Chi.-Kent L. Rev. 3 (1990) (collection of articles); Stephen M. Feldman, Republican Revival/ Interpretive Turn, 1992 Wis. L. Rev. 679; Frank I. Michelman, The Supreme Court 1985 Term: Foreward: Traces of Self-Government, 100 Harv. L. Rev. 4, 17-55 (1986). 
The republican tradition saw diffusion of power as an important element in institutional design. Private property, federalism, and judicial review thus served republican goals as well as liberal ones. Property provides the independent foundation that a citizen needs for proper consideration of the public interest. ....

Federalism . . . makes it easier for citizens to participate. . . Small scale dialogues lead citizens to understand that each of them has to subordinate self-interest to the public business if civic projects are to occur at all. ...

... Legislatures might become corrupt and disregard the plain meaning of the Constitution, but the independence given the judges makes it unlikely that they too will be corrupted. ${ }^{117}$

As this discussion suggests, and Professor Tushnet noted, "[A]s the framers considered questions of fundamental institutional design, they discovered that liberalism and civic republicanism converged on some important matters." 118 Thus, whether the framers and ratifiers were more influenced by Locke and the "classic liberal" views of the English Enlightenment tradition, or the Scottish and French Enlightenment traditions, or the civic Republican tradition, makes little difference at the end of the day. Professor Jefferson Powell has similarly noted, "While some advocates of the civic republican interpretation of the founding view republicanism as antithetical to liberalism, republicanism is better understood as a possible historical complement to liberalism. ... Even those whose commitment to Enlightenment politics was the most undeniable [citing James Madison, among others] saw no inconsistency in invoking the necessity of [the civic Republican concept of] civic virtue to free government as well."119

Of course, given the prevalent educational level of many individuals at the time, the concept of equal dignity of each individual based upon the ability to take another's perspective as well as one's own reflected in the Declaration of Independence and the civic Republican tradition was limited in practice by the concrete reality of the times. For example, although the Declaration of Independence stated in broad terms that all individuals are "created equal," the concrete customary practices of the times denied that equality to slaves, women, and even to many white men without property, who were all at that time denied various rights, including the right to vote.

This conflating of "reason" versus "custom" is typical of moral reasoning based upon concrete operational thought. Professor James Whitman noted this tendency in $18^{\text {th }}$-century thought in America, England, and Continental Europe in his article entitled Why Did the Revolutionary Lawyers Confuse Custom and Reason. He noted, "This Article offers a general historical account of how the

117 Mark Tushnet, Red, White \& Blue: A Critical Analysis of Constitutional Law 6-13 (1988).

$118 \quad$ Id. at 7.

119 H. Jefferson Powell, The Moral Tradition of American Constitutionalism 67, 69 (1993). See also Suzanna Sherry, Public Values and Private Virtue, 45 Hastings L.J. 1099 (1994) (complementary nature of civic Republicanism and liberalism). 
constitutionalist lawyers of the eighteenth-century world came to mingle ideas of customary right with characteristically eighteenth-century ideas of deductive natural law." ${ }^{20}$ Whitman stated:

Prime among such passages familiar to eighteenth-century readers was Bolingbroke's famous and influential statement: "By constitution we mean, whenever we speak with propriety and exactness, that assemblage of laws, institutions, and customs, derived from certain fixed principles of reason, directed to certain fixed objects of public good, that compose the general system, according to which the community hath agreed to be governed." 121

The limitations of concrete operational thought are reflected in an important limitation on moral reasoning at this level of cognitive thought. Because of concrete operational thought, there is a "fusion of fact and norm; when the [individual] first begins to cognize how an actor ought to act rather than how he does act, he has not yet clearly differentiated the two. What is morally right to do, then, tends to be defined in terms of what most people or most occupants of a particular role do in fact do." 122 This yields a morality based upon the conventional morality of one's peers, friends, and those with whom one interacts. As noted about Blackstone's theory of the common law:

The first and most famous principle was the idea that the source of common law is custom: that "the only method of proving, that this or that maxim is a rule of the common law is by showing that it hath been always the custom to observe it." The second principle was that custom itself was the expression of a nation's shared values, or, as we might say today, of its public conception of justice. "[R]eason is the life of the Law; nay the common Law itself is nothing else but reason ...." The equation of the common law with reason reflects a very special kind of natural law theory, one in which the source of natural justice was as much the people who were governed under the law as some independent moral truth that could be derived through philosophical reason. ${ }^{123}$

This conflating of custom and reason is precisely the basis for Justice Oliver Wendell Holmes' later criticism of natural law that "jurists who believed in natural law seemed to [Holmes] to be 'in that naive state of mind that accepts what has been familiar and accepted by them and their neighbors as something that must be accepted by all men everywhere." 124 As applied to natural law that relies on custom as one basis for reason, Holmes' criticism is right. It is not right, however, if applied to a natural law that is based solely on reason, and not on custom.

120 James Q. Whitman, Why Did the Revolutionary Lawyers Confuse Custom and Reason, 58 U. Chi. L. Rev. 1321, 1322 (1991).

121 Id. at 1325.

122 Kuhn, Langer, Kohlberg \& Hahn, The Development of Formal Operations in Logical and Moral Judgment, 95 Gen. Psych. Mono. 97, 137 (1977).

123 Anthony J. Sebok, Misunderstanding Positivism, 93 Mich. L. Rev. 2054, 2062 (1995).

124 Francis Biddle, Justice Holmes, Natural Law, and the Supreme Court 40-41 (1960). 
Despite this conflating of custom and reason by some of the Founding generation, their theory of constitutional interpretation would suggest that judges today should read the natural law concepts they placed into the Constitution in light of a cognitively advanced understanding of reason today, not their more limited custom or traditional notion of reason at the time. Under any version of traditional natural law interpretation - Enlightenment, Burkean, classic/Christian, or Augustinian - the intent of the Constitution is not the framers and ratifier's specific subjective intent, but rather the objective intent gleaned from applying traditional modes and canons of construction to the document's text. ${ }^{125}$ Under any of these versions of traditional natural law, critical advances in thought can help us see better today the permanent aspirations and truths reflected in that tradition, as opposed to the immediate preferences of those who drafted and ratified particular language. Persons holding such natural law beliefs would wish later generations to give a more enlightened interpretation to those natural law principles, as those principles are thought to exist independent of the more limited understanding any individual may have of those principles at any point in time.

With respect to the Enlightenment tradition, the Enlightenment concept of the social contract and government deriving its legitimacy from the consent of governed means that the Enlightenment tradition is to restrict judges to using natural law principles only to the extent those principles were adopted by the framers and ratifiers. ${ }^{126}$ The best evidence for such adoption would be explicit language, like that used in the First Amendment, Due Process Clause, and Equal Protection Clause. However, it is at least possible, consistent with the social contract approach, to argue that the framers and ratifiers themselves intended judges to resort to natural law principles outside the written text of the Constitution, and that this understanding was part of the society's social contract. ${ }^{127}$ This social contract approach is embedded, of course, in the Enlightenment view, most clearly stated by Locke, that each generation has a natural right of revolution against unjust regimes. ${ }^{128}$

Perhaps because England has no written constitution, or because the classic/Christian tradition assumes that natural law is an emanation of God's will and reason and is not dependent on a social contract, the classic/Christian tradition, as well as the Burkean tradition of $18^{\text {th }}$-century English

125 See generally H. Jefferson Powell, The Original Understanding of Original Intent, 98 Harv. L. Rev. 885, 887-902 (1985).

126 See David A.J. Richards, Foundations of American Constitutionalism 78-97 (1989).

127 See generally Suzanna Sherry, The Founders' Unwritten Constitution, 54 U. Chi. L. Rev. 1127 (1987); Terry Brennan, Natural Rights and the Constitution: The Original "Original Intent", 15 Harv. J.L. \& Pub. Pol'y 965 (1992). But see Helen K. Michael, The Role of Natural Law in Early American Constitutionalism: Did the Founders Contemplate Judicial Enforcement of "Unwritten" Individual Rights, 69 N.C.L. Rev. 421 (1991).

128 John Locke, Second Treatise on Government 240 (1690), cited in Huntington Cairns, Legal Philosophy from Plato to Hegel 336 (1949) ("Locke argued that government is established by society, and may therefore be disestablished by it. But who is the judge when the government has betrayed its trust to the extent necessary to justify an act of revolution. Locke answers, 'the people."'). 
political philosopher and writer Edmund Burke, appears more receptive to the argument that judges may occasionally supplement the natural law principles adopted by the framers and ratifiers with natural law principles derived from other sources, including religious ones. For example, such an insight, that judges have a pre-existing duty to God, appears to lie behind former Alabama Supreme Court Chief Justice Roy Moore's justification for his refusal in 2003 to order a Ten Commandments monument to be removed from the Alabama Supreme Court building.

However, as Professor Ernest Young has noted, Edmund Burke's use of tradition to shape judicial decisionmaking is restricted to "something internal to a tradition," though perhaps at an "aspirational, highly general" level. ${ }^{129}$ This position suggests that the Burkean approach, at least as Young envisioned it, agreed with the Enlightenment approach that judges should remain faithful to the moral concepts of the framers and ratifiers elaborated in a traditional common-law methodology. Professor Lee Strong has made the same point that the classic/Christian tradition, properly understood, commits the judge to an "original intent" interpretive methodology, ${ }^{130}$ although in his article Professor Strong confused the Enlightenment natural right of revolution against unjust regimes with a "non-originalist" interpretive methodology, which the Enlightenment tradition does not adopt, as noted above.

Another variation of the classic/Christian tradition is based on Augustine's views of man as "fallen from grace," and thus limited in ability to advance properly principles of "reason" and "love." One author, Professor Graham Walker, has argued that the framing and ratifying generation shared this Augustinian perspective on law and the judicial role. Professor Walker noted that an individual holding these views would counsel a certain amount of judicial restraint in decisionmaking since "if all interpreters partake of a morally vitiated human nature themselves, then responsible judges will be modest, wary, and self-critical as they interpret the Constitution - especially since their interpretive decisions affect many other people." 131

Under any of these versions of what the framers and ratifiers intended, a natural law approach does not commit the judge to the view that the concepts embedded in the Constitution have a static content that, when applied to concrete specific problems, have an unchanging meaning. That would not have been the understanding that any drafter would have had. As Professor David Richards has reminded us from the Enlightenment perspective, "No great political theory, including Locke's, is the last word on its own best interpretation, and critical advances in political theory may enable us better to understand and interpret the permanent truths implicit in the theory and to distinguish these

129 Ernest Young, Rediscovering Conservatism: Burkean Political Theory and Constitutional Interpretation, 72 N.C. L. Rev. 619, 689 (1994).

130 See Lee J. Strong, The Clash of Rival and Incompatible Philosophic Traditions Within Constitutional Interpretation: Originalism Grounded in the Central Western Philosophical Tradition, 28 Harv. J.L. Pub. Ply. 909 (2005).

131 Graham Walker, Moral Foundations of Constitutional Thought 125-27, 159, 168-70 (1990). 
from its lapsing untruths." 132 From a Burkean perspective, Professor Ernest Young noted that "the limits of human rationality require a constitution that can adapt in response to unforeseen difficulties, changed circumstances, and outright mistakes that any human endeavor will inevitably entail."133 From an Augustinian perspective, Professor Graham Walker noted that constitutional concepts are "timeless principles of human nature and political order," but, with respect to the framers and ratifiers, "[1]ike any of us, their immediate preferences were sometimes at odds with, and certainly did not exhaust, their aspirations." 134

In short, a person who wishes, consistent with a natural law tradition to apply consistently a general concept in which the individual believes, may have to adjust one or more specific views which currently are not consistent with that general concept. Through this process, a dynamic is created whereby over time more of an individual's specific views will be a reflection of reasoned elaboration of general moral concepts applied to current social realities, rather than specific views merely being the product of the individual's past experiences, unthinking adherence to tradition, idiosyncratic preferences, or prejudice. Under this view, while general concepts embedded in the Constitution do not change, and thus the Constitution should not be interpreted based on a mere reflection of judges legislating contemporary social policies from the bench, our understanding of what those general concepts mean in the Constitution when applied to specific fact situations can change over time.

This view obviously differs from those jurists, like Justices Scalia and Thomas, who think constitutional interpretation should involve viewing the Constitution as a static document, where the meaning of a constitutional provision, fixed at the time of ratification, can only be changed by later formal constitutional amendment. As Justice Scalia stated at a conference held in 2002, "The Constitution that I interpret and apply is not living, but dead. . . O Our first responsibility is not to make sense of the law - our first responsibility is to follow the text of the law."135 Justice Scalia similarly noted in his 1997 book, A Matter of Interpretation, that the alternative view of the "living" Constitution is incompatible "with the whole antievolutionary purpose of a constitution."136

From a natural law interpretation perspective, however, the framers and ratifiers would wish later generations to give the concepts they placed into the Constitution a more enlightened reasoning, since they were not putting into the Constitution their own fixed, subjective, specific views about some matter, but rather were placing into the Constitution broad natural law principles whose content they believed was independent of their specific views, and which would better be discovered over time through the application of reason. The framers were more humble about whether their current

132 Richards, supra note 126, at 13.

133 Young, supra note 129, at 668-69.

134 Walker, supra note 131, at 154-56.

135 Linda Greenhouse, The Competing Visions of the Role of the Court, New York Times, July 7, 2002, Section 4, page 3 .

136 Antonin Scalia, A Matter of Interpretation 44 (1997). 
reasoning fully reflected a complete understanding of the natural law principles in which they believed than those who support a fixed, static Constitution, like Justice Scalia, give them credit.

Justice Souter addressed this point regarding an evolving understanding of principles during his confirmation hearing in 1989. He noted, "Principles don't change but our perceptions of the world around us and the need for those principles do." ${ }^{137}$ Justice Kennedy reflected a similar point in 2003 in Lawrence $v$. Texas, which held unconstitutional laws criminalizing consensual sodomy. He noted for the Court, "Had those who drew and ratified the Due Process Clause of the Fifth Amendment or the Fourteenth Amendment known the components of liberty in its manifold possibilities, they might have been more specific. They did not presume to have this insight. They knew times can blind us to certain truths and later generations can see that laws once thought necessary and proper in fact serve only to oppress. As the Constitution endures, persons in every generation can invoke its principles in their own search for greater freedom." 138

In determining the content of these principles, the focus is not the specific policy goal that may have motivated a particular clause, but the broader, more generalized principle, or rule of law, that the clause established. As noted by Professor Leslie Goldstein, "[Chief Justice] Marshall carefully distinguished between the conscious, specific, policy goal that may have motivated a particular constitutional clause, on the one hand, and the broader, more generalized principle, or rule of law, that the clause established, on the other hand. For Marshall, constitutional law consisted of the latter rather than the former. For [individuals like Justice Scalia] the choice is the reverse." ${ }^{139}$ Justice Souter described this approach at his confirmation hearing as following the "original meaning" of the Constitution, rather than following specific "original intent." He stated, "[M]y interpretive position is not one that original intent is controlling, but that original meaning is controlling. . . . [Justices ought to identify the] principle that was intended to be established as opposed simply to the specific application that the particular provision was meant to have by, and that was in the minds of, those who proposed and framed and adopted that provision in the first place." 140

This difference between the specific examples of an idea versus the broader, more abstract concept or principle that the idea embodies, was noted by Professor Ronald Dworkin in his book Law's Empire. As he discussed there, conceptions are the specific, discrete ideas or examples held by individuals, while concepts are the broader, more abstract idea reflected in the conceptions. ${ }^{141}$ As elaborated by Professor Fallon:

137 See David H. Souter, Confirmation Hearings, cited in David J. Garrow, Justice Souter: A Surprising Kind of Conservative, N.Y. Times, September 25, 1994, sec. 6 (Magazine), at 52.

138 Lawrence v. Texas, 539 U.S. 558, 572, 578-79 (2003).

139 Leslie F. Goldstein, In Defense of Text 9 (1991).

140 David H. Souter, Confirmation Hearings, cited in David J. Garrow, Justice Souter: A Surprising Kind of Conservative, N.Y. Times, September 25, 1994, sec. 6 (Magazine), at 52.

141 See Ronald Dworkin, Law's Empire 71 (1986). 
One helpful division distinguishes between "specific" or "concrete" and "general" or "abstract" intent. Specific intent involves the relatively precise intent of the framers to control the outcomes of particular types of cases. . . A Abstract intent refers to aims that are defined as a higher level of generality, sometimes entailing consequences that the drafters did not specifically consider and that they might even have disapproved. An example comes from equal protection jurisprudence. The authors of the fourteenth amendment apparently did not specifically intend to abolish segregation in the public schools. Yet they did intend generally to establish a regime in which whites and blacks received equal protection of the laws - an aspiration than can be conceived, abstractly, as reaching far more broadly than the framers themselves specifically had intended. ${ }^{142}$

Professor Jefferson Powell has noted that this "progressive" mode of reasoning dependent on judicial "tradition," was shared by James Madison on the Republican side of early American politics, and by Alexander Hamilton and Chief Justice John Marshall on the Federalist side. Though some on the Republican side, including Thomas Jefferson, adopted arguments, similar to those of Justice Scalia, related to a plain meaning approach that viewed "constitutional propositions [as] deductions from static principles" from which "no argument from subsequent precedent, practice, or experience could change," ${ }^{143}$ that approach to constitutional interpretation was firmly rejected by early and continuous Supreme Court practice. Instead, the methodology of Madison, Hamilton, and Marshall triumphed on the Court.

In addition, Jefferson's approach must be considered against a backdrop of Jefferson's view that since "the earth belongs in usufruct to the living," each new generation has the right to make for itself a new Constitution. ${ }^{144}$ Under such a view, the Constitution would not be intended to endure for ages, but only until the next Constitution was adopted. A static, deductive model of interpretation makes better sense in such circumstances, for needed flexibility can come from newlyadopted constitutional language.

Under Jefferson's model of interpretation, for public policy initiatives which Jefferson supported, but which were of questionable constitutionality, like limited use of federal monies for internal improvements, Jefferson "felt that amendment of the Constitution" was the required means of action, rather than what he viewed as creative judicial interpretation. ${ }^{145}$ Even concerning the Louisiana Purchase, which was a very popular action, Jefferson preferred a constitutional amendment to ratify the purchase. As has been noted, "Although [Jefferson] eventually acquiesced in the Louisiana Purchase without the constitutional amendment that he believed was necessary to sanction it, what is noteworthy is the degree to which he agonized over what may be fairly regarded as a technical

142 See also Richard H. Fallon, Jr., A Constructivist Coherence Theory of Constitutional Interpretation, 100 Harv. L. Rev. 1189, 1198-99 (1987).

143 See Powell, supra note 119, at 92-100, 117.

144 David N. Mayer, The Constitutional Thought of Thomas Jefferson 302-08 (1994).

145 Id. at 218-19. 
question. Indeed, he was willing to jeopardize the acquisition of Louisiana, despite its immense strategic importance, in order to save the principle of strict [textual] construction."

Despite Jefferson's support, the view of constantly newly-adopted Constitutions was rejected by the framing and ratifying generation, including Jefferson's close friend James Madison. For Madison, "too frequent appeals to the people to 'new-model' government would 'in great measure deprive the government of that veneration, which time bestows on every thing, and without which perhaps the wisest and freest governments would not possess the requisite stability' . . . [Also] frequent reference of constitutional questions to the decision of the whole society raised 'the danger of disturbing the public tranquility by interesting too strongly the public passions." 147 As Chief Justice Marshall remarked in $\mathrm{McC}$ Culloch, "This provision is made in a constitution, intended to endure for ages to come, and consequently, to be adapted to the various crises of human affairs. To have prescribed the means by which government should, in all future time, execute its powers, would have been to change, entirely, the character of the instrument, and give it the properties of a legal code." 148 Unlike the detailed Constitutional Codes that emerged during the $19^{\text {th }}$ and $20^{\text {th }}$ centuries in European civil-law systems, our Constitution was not intended to be such a document.

Thus, although many of the framers and ratifiers may have been operating at a level of natural law where reason and custom were conflated, and thus they had flawed specific views regarding slavery, women's rights, or other such matters, as well as greater attention to widely-shared community norms like property rights, rather than equal concern and respect for all individuals, including protection for minority rights, ${ }^{149}$ their interpretive methodology would support judges today reasoning at the advanced level of moral reasoning when interpreting the natural law concepts they placed into the Constitution. Further, in following the "original intent" of the $14^{\text {th }}$ Amendment, it is important to remember that the Civil War Amendments were "Blue State" amendments, reflecting "Blue State" values, imposed on the "Red States" of the South.

In sum, only if the views of the framers and ratifiers were different than they were, or one decides that without regard to "original intent" judges should merely read clauses in the Constitution like the Equal Protection Clause or Due Process Clause to advance traditional or customary notions, can one plausibly adopt a "static" or "strict constructionist" model of constitutional interpretation to interpret concepts of equal protection and due process in light of the less cognitively-advanced, adolescent peer group mentality way of thinking about moral issues. Despite the views of many conservative Republicans, who support such customary or traditional moral views, and a strict constructionist model of interpretation, that model has little historical support in how the Founding generation, other than Jefferson, would have expected their Constitution to be interpreted.
146 Id. at 215 .
147 Id. at $300-01$.
14817 U.S. (4 Wheat.) 316, 415 (1819).
149 See William E. Nelson, Marbury v. Madison, Democracy, and the Rule of Law, 71 Tenn. L. Rev. 217, 218-28, 238 (2004). 
As discussed in Part II, the evolved understanding of reason from both a secular and religious perspective ends up at the same point, with a foundational principle of "equal concern and respect" for all individuals, alternatively phrased as "love of neighbor as thyself." Thus, while various versions of $18^{\text {th }}$-century Enlightenment, Burkean, classic/Christian, or Augustinian traditions did have some substantive disagreements over the content of natural law, those disagreements disappear as each tradition moves into its more evolved understanding of the demands of reason and truth.

Similarly, one way to understand Jesus' message in the Bible is that Jesus was thinking of the principle of "love of neighbor" from the perspective of universal human rights based on giving equal concern and respect to all human beings. This perspective would support a reasoned understanding of biblical passages today, despite the fact that the gospels were written at a time when most individuals in society were operating in the context of societies based on the self-interest of childish egocentricism or the customs and traditions of adolescents, and for many centuries the Catholic and Protestant traditions read the Bible from those perspectives.

For example, a reasoned perspective would not support the anti-Semitism of most Catholic and Protestant traditions until recent Vatican II modernization, even though that anti-Semitism was part of almost 2000 years of Christian self-interest, and the customs and traditions of the Christian faith. Similarly, a reasoned perspective would not support an interpretation of the Bible based upon an "Old Testament" God as punisher interpretation of the Bible, or "Pope as dictatorial interpreter of the Bible," or "community of the faithful" interpretation of the Bible, or traditional literalist interpretation of the Bible, each of which was used for many centuries to support slavery, segregation, and anti-miscegenation laws. When religious conservatives extolling customs and traditions claim to be acting in Christ's name, that is unlikely to be true. Christ did not walk through Galilee extolling the virtues of the existing Philistine customs and traditions, based on an adolescent peer group mentality way of thinking. His message was a transformative message of "love of neighbor as oneself" for all individuals - the mature, adult, rational kind of moral reasoning.

\section{Part IV. Moral Deliberation Based Upon Reason in American Constitutional Law}

The thesis of this section is that moral reasoning based upon reason is likely to be found increasingly as a guide in American constitutional law, as well as in American society generally and in its legal system. Predicting this is a chancy venture, as may be seen by considering the difficulties of an attempt in 1953 to predict what constitutional law would include by 1986. A predictor in 1953 would probably not have found it likely that the Court would soon end segregation in public facilities, recognize a fundamental right to choose abortion, expand First Amendment protection to commercial speech, and provide a host of new protections for defendants in criminal cases. The problem is even more complex because the Court has been more cautious since 1986 with respect to identifying additional fundamental rights and has given increased weight to concerns of federalism and protecting state governments from lawsuits brought by citizens seeking to vindicate individual rights.

The project starts with certain assumptions. First, such a society will deal with moral reasoning by the use of reason, rather than by customs or traditions. Second, rational thought is not egocentric, but supports the principle of love of neighbor as oneself, which can also be expressed as equal 
concern and respect for others, or behave according to the logic of an impartial spectator. Third, when attempting to put further content into moral reasoning, an effort should be made to avoid irrational perspectives or prisms, and only to infer principles directly derivable from the principle of love of neighbor as oneself, such as not taking innocent life, respecting other persons' bodily integrity and personal property, and not lying to other people for one's personal gain.

It is also necessary to remember that there is a distinction between what rational moral reasoning may dictate with regard to personal behavior and what it suggests regarding the discretionary power of law makers and the provisions of a constitution designed to limit that power. In addition, although giving individuals equal concern and respect naturally calls for providing adequate remedies for persons who have been oppressed, that does not automatically translate into a legislative duty or a fundamental constitutional right for the government to provide food, housing, and other needs for all individuals who are poor. Also, legislative provision for the poor or disabled may reduce any pressure felt by the Court to find in the Constitution some protections for those and similar groups.

In addition, unless the Supreme Court majority adopts some kind of radical, Platonic Guardian model of judicial decisionmaking, where Justices would feel free to impose their policy views without reference to the original intent of the framers and ratifiers, Court decisions will also be limited by the requirement to balance any arguments based upon background moral reasoning of principles embedded in the Constitution viewed from the perspective of adult reason against the requirements of constitutional text, purpose, context, history, practice, and precedent. From this perspective, it is important to note that our constitutional tradition is based upon a model that constitutional rights are there to protect individuals from governmental regulation, and to ensure individuals have an equal opportunity to compete. There is no tradition recognizing group rights in our constitutional history, and only with rare exceptions, like the Sixth Amendment right to counsel funded by the government for indigent defendants, does any concept of a right to funding, or right to equal results, come into play.

This tradition is consistent with a rational understanding of rights. On the issue of individual versus group rights, from the perspective of rational thought, only individuals exist. There can, of course, be a group of individuals. However, there is no such thing as a group that is independent of the individuals that make up the group. The term "group" is merely a short-hand reference for the individuals who are in that group. To the extent those individuals all have some right, then everyone in the group will have that right. But rights belong to individuals who are entitled, from a rational perspective, to equal concern and respect. From a logical standpoint, there is no such thing as a group that exists independent of its members; thus, groups cannot have natural rights. ${ }^{150}$

This is true even if discrimination practiced upon some individuals is practiced because of their membership in a group. For example, historically African-Americans were discrimination against by Jim Crow legislation because of their membership in a racial group, being African-American.

150 For a contrary argument that it is possible, and appropriate, to sometimes think of rights in "group right" terms, independent of the rights of individuals in the group, see, e.g., Ronald R. Garet, Community and Existence: The Rights of Groups, 56 S. Cal. L. Rev. 1001 (1983). 
Such unjust treatment would entitle any individual African-American so discriminated against to an appropriate remedy. From the perspective of reason, however, that discrimination against an individual based upon group membership would not entitle every member of that group, that is every African-American, to the same level of remedial treatment. For example, an African-American family living in a progressive community that never engaged in any discrimination against that family, and no direct discrimination against any of their ancestors, so that only a modest claim of some indirect intergenerational effects of discrimination against prior individuals in that family could be made, would be entitled to only very modest relief.

Even more so, discrimination against one racial minority group would not entitle members of a different racial minority group to a remedy on the basis that all racial minorities are members of the larger group of minorities generally, and thus discrimination against any part of that group is discrimination against all. As Justice O'Connor phrased this point in Richmond v. Croson, "The foregoing analysis applies only the inclusion of blacks within the Richmond set-aside program. There is absolutely no evidence of past discrimination against Spanish-speaking, Oriental, Indian, Eskimo, or Aleut persons in any aspect of the Richmond construction industry." 151

Equally, merely because a group may not be stigmatized by some action, that would not mean that individuals in that group harmed by discrimination should not have an appropriate remedy. For example, one might argue that affirmative action on behalf of minorities does not send a message of stigmatization to white persons as a group. ${ }^{152}$ Even if that were true, if individual white persons are harmed by the effects of some affirmative action program, they should be able to raise a complaint and have that complaint tested by strict scrutiny applicable to racial discrimination cases.

A reasoned understanding of a right to equal opportunity and autonomy versus a right to equal results or funding is more complex. The baseline issue, of course, is what are the demands of treating each individual with equal concern and respect. To the extent that individuals are viewed as having free will, individuals are thus charged with some responsibility for their actions. This would mean that not all individuals are entitled to equal results in all circumstances, because individuals engaging in different actions, for which those individuals are responsible, will naturally lead to different results. Such reasoning leads in the direction of viewing rights to equal concern and respect as rights to equal opportunity and equal autonomy.

On the other hand, all individuals have different genetic predispositions in certain areas with which they were born and which are not the product of their free will choice. In extreme circumstances, for example, some individuals are born with genetic mental or physical impairments that place them at a disadvantage to others. For such individuals, any rational concept of equal opportunity or equal autonomy will require some affirmative funding by the members of the rest of society to help equalize those disadvantages. Of course, as noted above, to the extent legislative provision is made

151488 U.S. 469, 506 (1989).

152 See, e.g., Deborah Hellman, The Expressive Dimension of Equal Protection, 85 Minn. L. Rev. 1, 17 (2000). 
for such individuals in statutes, like the Americans with Disabilities Act, which provides some response to issues of equal access and equal opportunities for the disabled, any pressure felt by the Supreme Court to find in the Constitution protections for such individuals will be reduced.

From the perspective of a rational thinker, a society that embodies to a substantial extent in its laws the principle of "equal concern and respect" deserves that individual's obedience on "moral" grounds. Societies at earlier levels of morality deserve respect on "sociological" grounds to the extent working within the system is more likely to help that society evolve toward such principles, rather than engaging in civil disobedience or civil revolution. From a reasoned perspective, "legal" grounds, while necessary from the perspective of "equal concern and respect" to legitimate a constitution do not provide sufficient legitimacy for law. Differences among "moral" versus "sociological" versus "legal" grounds for obedience toward law are reflected in recent writing about the duty to obey and law and constitutional legitimacy by Professor Richard Fallon. ${ }^{153}$

Adoption of this approach to moral reasoning will likely be done in the future not because it can be proved this approach is more moral, which under Godel's theory cannot be done, as discussed in Part II, Section B, but because it is the approach adopted by a fully rational person who understands this is the only basis for rational agreement among members in society. Any other system, because ultimately based on irrational first principles, can obtain societal consensus only through force either military force, psychological conditioning, or social pressure. It will also likely occur because history suggests that more educated people tend to adopt more cognitively advanced principles of morality, and for the religious among them, are able to revise their interpretation of religious texts to reflect those principles, given the language of, and inherent flexibility in, religious texts.

The core question for reason in terms of constitutional law is what principles are likely to be reflected in the Constitution as a product of rational moral reasoning. How quickly this may happen, and with what level of success, will depend partially upon events in the political realm, including whom the President appoints and the Senate confirms to serve on the Supreme Court. In addition, any change in constitutional law depends in part on what cases or controversies get litigated, and are presented to the Court for decision. It can be predicted, however, that the Court will continue to grapple with such matters as separation of powers, federalism, affirmative action, freedom of speech, and the separation of church and state. All of these issues involve conflicts in a democratic society between majoritarian power and individual freedom, or between central and dispersed governmental power.

Dealing with this issue calls for a revision of perspective to viewing the Court's role as promoting, within the limitations of a social contract natural law theory of constitutional interpretation, the vision of love of neighbor as oneself, or equal concern and respect, or behave according to the logic of the impartial spectator. An analogy to a similar revision in perspective was Justice Holmes' insight in Lochner $v$. New York that the majority, which had found no sufficient relationship between a maximum hours work requirement and the health of bakery employees, was applying a particular economic theory. That allowed Holmes to utter words which later became orthodox theory, "But

153 Richard H. Fallon, Jr., Legitimacy and the Constitution, 118 Harv. L. Rev. 1787 (2005). 
a constitution is not intended to embody a particular economic theory, whether of paternalism and the organic relation of the citizen to the state or of laissez faire. It is made for people of fundamentally differing views, and the accident of our finding certain opinions natural and familiar, or novel, and even shocking ought not to conclude our judgment upon the question whether statutes embodying them conflict with the Constitution of the United States."

Just as Justice Holmes' new perspective, initially uttered in dissent, changed constitutional law once it became adopted by a majority of Supreme Court Justices after 1937, the new reasoned perspective, although initially represented in a number of dissenting or concurring opinions, may gradually be emerging in majority opinions, typically by Justices O'Connor, Kennedy, or Souter, but also in opinions by Justice Stevens. The fundamental idea behind this perspective is that governmental action should be tested by whether its means and ends accord with the logic of an impartial spectator, which requires giving each person equal concern and respect.

Justice Stevens has made repeated use of the idea that government has a duty to govern impartially. For example, in FCC v. Beach Communications, Inc., the Court allowed federal cable television regulations to distinguish between facilities that served separately owned and managed buildings and those that served several buildings under common ownership or management. In his concurring opinion, Justice Stevens said that "it is reasonable to presume that Congress was motivated by an interest in allowing property owners to exercise freedom in the use of their own property. Legislation so motivated surely does not violate the sovereign's duty to govern impartially."155

In a footnote in his Beach Communications concurrence, Justice Stevens also stated, "[W]hen the actual rationale for the legislative classification is unclear, we should inquire whether the classification is rationally related to 'a legitimate purpose that we may reasonably presume to have motivated an impartial legislature." "156 This requirement of an "impartial legislature," rather than deference to any conceivable legislative purpose, is reflected in the requirement, discussed in Part III, that the legislature not advance irrational prejudices or irrational stereotypes, even if those prejudices or stereotypes are consistent with the customs and traditions of society.

In Michael M. v. Superior Court, ${ }^{157}$ the majority rejected an equal protection challenge to California's statutory rape law which made men alone criminally liable for sexual intercourse with a female under the age of 18 years. Justice Stevens dissented. He said, "Even if . . there actually is some speculative basis for treating equally guilty males and females differently, . . . any such speculative justification would be outweighed by the paramount interest in evenhanded enforcement of the law. A rule that authorizes punishment of only one of two equally guilty wrongdoers violates
154198 U.S. 45, 74 (1905) (Holmes, J., dissenting).
508 U.S. 307, 311-13 (1993); id. at 323 (Stevens, J., concurring in the judgment).
Id. at 323 n.3 (Stevens, J., concurring in the judgment).
157
450 U.S. 464, 470-74 (1981). 
the essence of the constitutional requirement that the sovereign must govern impartially."158

An area in which government impartiality or neutrality has been expressly recognized by the Court as a significant factor is the Establishment Clause. For example, in Rosenberger v. Rector and Visitors of the University of Virginia, the Court held that the Establishment Clause did not compel a university to exclude an otherwise eligible student publication from participating in the student activities fund solely on the basis of its religious viewpoint. Justice Kennedy stated, "A central lesson of our decisions is that a significant factor in upholding governmental programs in the face of Establishment Clause attack is their neutrality toward religion." 159 The Court reached a similar result regarding charging students a student activity fee used to facilitate extracurricular student speech that was viewpoint neutral in Board of Regents of the University of Wisconsin System $v$. Southworth. ${ }^{160}$

Because a reasoned approach to interpretation would adopt an analytic approach toward judicial decisionmaking, a Court following such a reasoned approach should consider fully the analytic goal of certainty and predictability in the law, which often suggests a categorical approach toward doctrine, versus the normative goal of fundamental fairness in each case, which often supports an inquiry into all the circumstances in the case. Justice Stevens' opinion for the Court reflected this balance in Tahoe-Sierra Preservation Council, Inc. v. Tahoe Regional Planning Agency, where the Court refused to create a categorical rule that a moratoria on building which lasted more than a year was a compensable taking. Justice Stevens explained that "the ultimate constitutional question is whether the concepts of 'fairness and justice' that underlie the Takings Clause will be better served by one of these categorical rules or by a Penn Central inquiry into all of the relevant circumstances in particular cases.",161

From this perspective, an effort also should be made to avoid particular perspectives or prisms, so as to ensure that the Court is not inferring principles beyond those directly derivable from the foundational principle of love of neighbor as oneself. This perspective supports rejecting use of mere contemporary social policy, which places the Court in the position of legislating from the bench by making decisions for society reflecting a particular public policy prism. In contrast, a reasoned Court should restrict itself to protecting the core background principles of justice embedded in a reasoned understanding of constitutional concepts, including both "liberty" and "equality" in the $14^{\text {th }}$ Amendment. ${ }^{162}$

Id. at 502 (Stevens, J., dissenting).

159515 U.S. 819, 839 (1995) (Kennedy, J., for the Court).

160529 U.S. 217, 220-21 (2000) (Kennedy, J., for the Court).

161535 U.S. 302,334 (2002) (Stevens, J., for the Court).

162 On the importance of Court scrutiny being equally vigorous for liberty, as well as equality, see Rebecca Brown, Liberty, The New Equality, 77 N.Y.U. L. Rev. 1491 (2002). 
For example, the opinions of Justices Stevens and Blackmun in Planned Parenthood v. Casey followed Roe v. Wade in its entirety, making every burden on abortion rights subject to strict scrutiny. ${ }^{163}$ This constitutionalized under a strict scrutiny approach all regulations on abortion, following Roe's concern about specific harm if a pro-choice position were not adopted. ${ }^{164}$ This approach differed from the approach of the joint opinion in Casey, where the Court did not sit as a super-legislature regarding all aspects of abortion regulation. Thus, the specific harm paragraph in Roe was not present in Justices O'Connor, Kennedy, and Souter's joint opinion in Casey, and not every regulation of abortion was examined under a strict scrutiny approach. ${ }^{165}$ The importance of the undue burden analysis in the joint opinion in Casey was to ensure that not every abortion regulation triggers strict scrutiny, and thus the Court does not act as super-legislature secondguessing every aspect of abortion regulation, but rather restricts the strict scrutiny analysis to protecting the core principle of liberty at issue in the case. ${ }^{166}$

The Court has applied this undue burden analysis in other unenumerated fundamental rights cases. For example, in cases involving the right to marry, the Court has applied strict scrutiny to the "significant" and "substantial" infringement at issue in Zablocki v. Redhail, but only rational review to a burden on the right to marry of a prisoner in Turner v. Safley. ${ }^{167}$ Similarly, the Court has applied strict scrutiny to significant burdens on the right to travel, as in Shapiro v. Thompson and Memorial

163505 U.S. 833, 917 (1992) (Stevens, J., concurring in part and dissenting in part); id. at 92934 (Blackmun, J., concurring in part and dissenting in part).

164 See Casey, 505 U.S. at 927-28 (Blackmun, J., concurring in part and dissenting in part) ("[C]ompelled continuation of a pregnancy . . . impos[es] substantial physical intrusions and significant risks of physical harm. . . . [M]otherhood has a dramatic impact on a woman's educational prospects, employment opportunities, and self-determination . ...”); Roe v. Wade, 410 U.S. 113, 153 (1973) (Blackmun, J., for the Court) ("Maternity, or additional offspring, may force upon the woman a distressful life and future. Psychological harm may be imminent. Mental and physical health may be taxed by child care. There is also the distress, for all concerned .....").

165 Compare 505 U.S. at 934-40 (Blackmun, J., opinion) (applying strict scrutiny to all of the legislative regulations at issue in Casey) with id. at 879-901 (joint opinion in Casey) (rational review applied to less than undue burdens on abortion choice; strict scrutiny applied only to the spousal notification provision which was held to constitute an undue burden on abortion choice).

166 Note that it could be argued that the joint opinion in Casey summarily concluded that the spousal notification provision was unconstitutional once it was held to be an undue burden. See id. at 877 ("In our considered judgment, an undue burden is an unconstitutional burden."). However, the better analysis of Casey is that when the joint opinion stated it was upholding the core holding of Roe, id. at 846, 869-71, that meant a court should apply Roe's strict scrutiny analysis to undue burdens on abortion rights.

167 Safley, 82 U.S. 78 (1987); Zablocki, 434 U.S. 374, 386-87 (1978). 
Hospital v. Maricopa County, ${ }^{168}$ while applying only rational review to other burdens on the right to travel, as in Zobel v. Williams and Hooper v. Bernalillo County Assessor. ${ }^{169}$ In cases involving the right to vote, the Court has applied strict scrutiny for more severe burdens on the right to vote, as in Kramer v. Union Free School District, ${ }^{170}$ while only applying rational review to less severe burdens, such as restrictions on voting for a water reclamation district in Ball v. James, ${ }^{171}$ or limitations on the voting rights of prisoners, in O'Brien v. Skinner. ${ }^{172}$

This use of undue/substantial burden analysis is consistent with a Court adopting an impartial spectator approach, rather than sitting as a super-legislature. From this perspective of reason, basic principles of liberty and equality must be protected, since every individual has an equal right not to have imposed upon them other individuals' non-rationally supported moral prisms. However, once that protection is assured, there are a number of collateral decisions that any society must make in order to assure persons can live together in peace and harmony with equal concern and respect given to all. Given the institutional competencies of each branch of government, these collateral decisions are best made in most circumstances by democratically elected officials, rather than courts.

For this reason, it is likely that a reasoned Court will use this undue/substantial burdens versus lesser burdens analysis in an increasing number of areas of the law. In each of these cases, the Court will have to consider what form of rational review analysis should be applied. Though the Court has suggested it was applying minimum rational review in the cases cited above, the actual reasoning in the opinions suggests more a "second-order" or "rational review with bite" factor balancing approach. ${ }^{173}$ A similar case involving "second-order" or heightened rational review for a less than severe burden on associational rights in case of ballot access is Timmons v. Twin Cities Area New Party. ${ }^{174}$

168 Shapiro, 394 U.S. 618 (1969); Maricopa County, 415 U.S. 250 (1974).

169 Zobel, 457 U.S. 55 (1982); Hooper, 472 U.S. 612 (1985).

170 Kramer, 395 U.S. 621 (1969).

171 Ball, 451 U.S. 355 (1981).

172 Skinner, 414 U.S. 524 (1974).

173 For discussion suggesting understanding of the undue burden analysis in this way, see R. Randall Kelso, Filling Gaps in the Supreme Court's Approach to the Constitutional Review of Legislation: Standards, Ends, and Burdens Reconsidered, 33 S. Tex. L. Rev. 493, 510-12, 596-99 (1992); R. Randall Kelso, Three Years Hence: An Update on Filling Gaps in the Supreme Court's Approach to Constitutional Review of Legislation, 36 S. Tex. L. Rev. 1, 9-11 (1995).

174 This view of Timmons appears in R. Randall Kelso, Standards of Review Under the Equal Protection Clause and Related Constitutional Doctrines Protecting Individual Rights: The "Base Plus Six” Model and Modern Supreme Court Practice, 4 U. Pa. J. Const. L. 225, 248-29 (2002). 
This impartial spectator approach similarly supports an analysis permitting "play in the joints" for social policy decisions, rather than constitutionalizing value decisions not determined by the principle of equal concern and respect, or the logic of the impartial spectator. This is reflected in cases like Locke v. Davey, ${ }^{175}$ where the Court read the Free Exercise Clause and Establishment Clause in 2004 to permit the legislature sufficient "play in the joints" to make the policy decision whether to fund scholarships to be used for religious training.

Similar deference to policy decisions of others, consistent with a concern for giving all individuals equal concern and respect, is reflected in the Court upholding in Grutter v. Bollinger the University of Michigan Law School's use of race in its admission process. A particular circumstance given weight by the Court was the university's judgment that diversity would produce educational benefits. Justice O'Connor said for the Court, "Our scrutiny of the interest asserted by the Law School is not less strict for taking into account complex educational judgments in an area that lies primarily within the expertise of the university. Our holding today is in keeping with our tradition of giving a degree of deference to a university's academic decisions, within constitutionally prescribed limits."176

This deference is understandable. The real question of government ends in these cases is whether there is a compelling government interest in effective and efficient education. That is the end that governments seek regarding education. ${ }^{177}$ Diversity in the student body is one means to obtain this end. As Justice Powell indicated in Bakke v. Regents of the University of California, merely having diversity for diversity's sake is not only not a compelling government interest, it is not even a legitimate interest. Justice Powell stated, "If petitioner's purpose is to assure within its student body some specified percentage of a particular group merely because of its race or ethnic origin, such a preferential purpose must be rejected not as insubstantial but as facially invalid. Preferring members of any one group for no reason other than race or ethnic origin is discrimination for its own sake. This the Constitution forbids." 178 Properly understood, then, the strict scrutiny analysis that takes place in race-based affirmative action cases involving education involves: (1) is there a compelling governmental interest in effective and efficient education; (2) is having a diverse student body directly and substantially related to advancing this interest, and (3) is the affirmative action program adopted the least restrictive alternative that would effectively advance the government's compelling interest in education.

Deferring to academic judgment, the Court decided in Grutter that having a racially diverse student body is directly and substantially related to the compelling governmental interest in effective and efficient education. Under strict scrutiny, however, any race-based affirmative action program must

175 Locke v. Davey, 540 U.S. 712 (2004).

176 Grutter v. Bollinger, 539 U.S. 302, 328 (2003).

177 See generally Hunter v. Regents of the Univ. of Cal., 190 F.3d 1061, 1063 ( $9^{\text {th }}$ Cir. 1999), citing Brown v. Board of Educ., 347 U.S. 483, 493 (1954) (“[E]ducation is perhaps the most important function of state and local governments.").

178 Bakke, 438 U.S. 265, 307 (1978) (Powell, J., opinion). 
be the least restrictive alternative to achieving these educational benefits. This test was held in Grutter to be satisfied by the University of Michigan's Law School admissions program, which used race as merely one of many factors involved in a process that reviewed individual student application files. In contrast, the Court decided in Gratz v. Bollinger ${ }^{179}$ that the rigid absolute point system preference of the University of Michigan undergraduate program was unconstitutional, since it was not the least restrictive effective alternative to achieve the benefits of a racially diverse student body.

Considering affirmative action more broadly, race-based affirmative action can be justified as a remedy for prior racial discrimination under current doctrine. As Justice O'Connor has noted, “The unhappy persistence of both the practice and the lingering effects of racial discrimination against minority groups in this country is an unfortunate reality, and the government is not disqualified from acting in response to it." 180 Such discrimination can take many forms. A full account of such discrimination would take into account the burdens suffered today by the intergenerational effects of discrimination practiced against parents, grandparents, and great-grandparents in the past. Such an intergenerational transmission of inequality "shows how 'an oppressive racial legacy continues to shape American society through the reproduction of inequality generation after generation." 181

For example, in the context of admissions programs to colleges and universities, alumni connections can play a large role. Potential for contributions to the university by parents of applicants with wealth can also make a difference. Better schools in middle or upper-middle class neighborhoods, or funds to take standardized test training courses, can also be an advantage in admittance to colleges and universities. The intergenerational effects of past discrimination on today's minority individuals mean that many of them will not share equally in these advantages more widely shared by middle and upper-middle class white applicants. ${ }^{182}$ In the workplace, a similar disparity exists in many cases in terms of connections and networking of parents and extended family members. As has been noted, "The glass ceiling remains a barrier for women and people of color largely because of patterns of interaction, informal norms, networking, training, mentoring, and evaluation, as well as the absence of systematic efforts to address bias produced by these patterns." "183

179539 U.S. 234, 270-72 (2003); id. at 276-80 (O’Connor, J., concurring).

180 Adarand Constr. Co. v. Pena, 515 U.S. 200, 237 (1995) (O’Connor, J., opinion).

181 Joan Tarpley, A Comment on Justice O'Connor's Quest for Power and Its Impact on African-American Wealth, 53 S.C. L. Rev. 117, 132 (2001), quoting Melvin L. Oliver \& Thomas M. Shapiro, Black Wealth/White Wealth 128 (1995).

182 See generally Richard Delgado, Official Elitism or Institutional Self-Interest?, 34 U.C. Davis L. Rev. 593, 601-05 (2001); Jody David Armour, Hype and Reality in Affirmative Action, 68 U. Colo. L. Rev. 1173, 1176-77, 1195-98 (1997); Iham Kim, Book Note: Derek Bok and William Bowen: The Shape of the River: Long-Term Consequences of Considering Race in College and University Admissions, 4 Mich. J. Race \& L. 145, 148-49 (1988).

183 Susan Sturm, Second Generation Employment Discrimination: A Structural Approach, 101 Colum. L. Rev. 458, 469 (2001) 
In some circumstances, critics of race-based affirmative action appear to take these advantages for granted, and thus complain about any other individual getting any kind of advantage set to equalize these effects. Some individuals tend to focus on the immediate admissions or hiring decision being made, rather than the more difficult task of working through longer chains of causation necessary to consider fully the intergenerational effects of prior racial discrimination. Nonetheless, despite this reality, there is an understandable concern that any consideration of race betrays the promise of the Equal Protection Clause that America should be a "color-blind" society. As Justice Scalia has stated, "In the eyes of government, we are just one race here. It is American." "184 Given America's history, however, an abrupt end to affirmative action today might well increase racial tensions rather than reduce them. Given our Nation's history, Justice Blackmun's remark in Baake that "to get beyond racism, we must first take account of race" may be more empirically accurate. ${ }^{185}$

Nevertheless, Justice Blackmun's remark in Bakke concerning the need to eventually "get beyond racism" is important. This remark was echoed in Justice O'Connor's opinion in Grutter in two ways. First, she noted, "It has been 25 years since Justice Powell first approved the use of race to further an interest in student body diversity in the context of higher education. ... We expect that 25 years from now, the use of racial preferences will no longer be necessary to further the interest approved today." 186 Second, in the absence of prior racial discrimination to which race-based affirmative action is a necessary remedy, whether or not to adopt a race-based affirmative action program is within the discretion of society's policy-makers. Justice O'Connor noted, 'Universities in California, Florida, and Washington State, where racial preferences in admissions are prohibited by state law, are currently engaged in experimenting with a wide variety of alternative approaches." 187

One alternative approach is represented by the so-called "Hyde Park Declaration," a New Democrat policy statement that recommends that the goal for 2010 should be to "shift the emphasis of affirmative action strategies" away from race-based affirmative action toward "economic empowerment of all disadvantaged citizens." ${ }^{188}$ Such a proposal is consistent with the premise of equal concern and respect for all citizens and the desire to leave no child behind, while also responsive to the concern that American society should eventually being able to deal justly with the legacy of past racism and achieve in the future a just color-blind society of equal dignity for all individuals regardless of race or ethnicity.

184 Adarand, 515 U.S. 200, 239 (1995) (Scalia, J., concurring in part).

185 Bakke, 438 U.S. at 407 (Blackmun, J., concurring).

186 Grutter, 539 U.S. at 342-43 (O’Connor, J., opinion for the Court).

187 Id. at 343.

188 The Hyde Park Declaration: A Statement of Principles and a Policy Agenda for the $21^{s t}$ Century (Aug. 1, 2000) (available from an internet search using the key words in the document's title). 
Generalizing from the topic of diversity in education, and from the concept of impartiality in law, a reasoned Court will be likely to uphold efforts to achieve diversity and will apply its standards of review to require governmental toleration of ever more diverse ideas and behavior. Such a Court will protect freedom of speech, except where in the circumstances the expression represents, as under current doctrine, a real threat of harm to others. ${ }^{189}$ Groups that do not embrace this vision of toleration will be tolerated by the government and the courts only to the extent that they are isolated or ineffective in their practices because at all individuals should be protected from group domination. Because of the universality of these principles of morality, this protection from domination would extend not only to domestic law, but also to rooting out intolerant groups of global reach.

With regard to federalism and separation of powers concerns, the notion of the impartial spectator should mean that the Court should not take sides in choices regarding federal versus state power, or legislative versus executive power, as long as those choices are within constitutional limits. In our history conservative judges have tended to favor states' rights and the executive branch in these kind of cases, while liberal judges have tended to favor the federal government and the legislative branch. An impartial spectator would reject either kind of favoritism. Such an approach would acknowledge that, within broad limits concerned with preventing tyranny against individual citizens, yet assuring sufficient governmental efficiency, most issues of federalism and separation of powers, like the issue of whether or not to follow a kosher diet, discussed at Part II, Section B, merely represent differing choices particular countries around the world have made. For these issues, therefore, without any background moral principles to help resolve particular issues, the considerations of text, context, history, and practice should become more prominent in the Court's opinions.

As many commentators have noted, Justice Souter's view on the $11^{\text {th }}$ Amendment, limiting state sovereign immunity under the $11^{\text {th }}$ Amendment to diversity jurisdiction in federal courts, best represents the text of the Constitution, the history surrounding its adoption, the Enlightenment vision on issues of sovereign immunity, and early Court precedents. ${ }^{190}$ Additionally, one view of the $14^{\text {th }}$ Amendment Privileges or Immunities Clause is that it was intended, in part, to give each citizen of the United States a right to have federal law enforced in the states. ${ }^{191}$ Of course, a majority of conservative judges in 1890 in Hans v. Louisiana, and a majority of conservative judges in a number of recent cases, including in 1999 in Alden v. Maine, ${ }^{192}$ have adopted a broader, more states'-rights

189 See Virginia v. Black, 538 U.S. 343 (2003) (speech true threat to others); Brandenburg v. Ohio, 395 U.S. 444 (1969) (advocacy of others engaging in illegal conduct).

190 See generally John F. Manning, The Eleventh Amendment and the Reading of Precise Constitutional Text, 113 Yale L.J. 1663, 1665-73 (2004); Erwin Chemerinsky, The Hypocrisy of Alden v. Maine: Judicial Review, Sovereign Immunity, and the Rehnquist Court, 33 Loyola L.A. L. Rev. 1283, 1303-08 (2000).

191 See generally William J. Rich, Taking “Privileges and Immunities” Seriously: A Call to Expand the Constitutional Canon, 87 Minn. L. Rev. 153, 181-83, 200-10 (2002); William J. Rich, Privileges or Immunities: The Missing Link in Establishing Congressional Power to Abrogate State Eleventh Amendment Immunity, 28 Hastings Const. L.Q. 235 (2001).

192 Alden, 527 U.S. 706, 715-27 (1999); Hans, 134 U.S. 1, 14-15 (1890). 
vision of state sovereign immunity. An approach more consistent with text and history of the original Constitution and the $14^{\text {th }}$ Amendment, and more consistent with the Court not imposing policy choices on society, but deferring to the legislature where those choices are not required by the Constitution, would permit Congress by statute to determine whether individuals should be permitted to sue states for violation of federal law, rather than the Court preempting that decision.

This would require overruling the Court's recent $11^{\text {th }}$ Amendment jurisprudence on the ground that those decisions are substantially wrong as reflecting too great a conservative preference for states' rights, a preference not adequately represented in constitutional text, context, history, and practice. This would mirror the Court's rejection in $10^{\text {th }}$ Amendment doctrine of the greater conservative preference for states' rights represented in National League of Cities v. Usery, and its replacement by the more balanced and textually faithful analysis of the $10^{\text {th }}$ Amendment in Garcia v. San Antonio Metropolitan Transit Authority. ${ }^{193}$

For separation of powers cases, the Court should similarly reject any conservative preference for the executive branch, or liberal preference for the legislative branch, in favor of an impartial spectator approach toward executive versus legislative power issues in light of constitutional text, context, history, practice, precedent, and prudential considerations. In deciding such separation of powers cases, a judge must ask whether the framers and ratifiers adopted a strict separation of powers approach, or whether they adopted a constitution that focused more on sharing of powers and checks and balances. In an opinion joined by all Justices on the Court except Justice Scalia, Justice Blackmun wrote in Mistretta v. United States:

In applying the principle of separated powers in our jurisprudence, we have sought to give life to Madison's view of the appropriate relationship among the three coequal Branches. Accordingly, we have recognized, as Madison admonished at the founding, that while our Constitution mandates that 'each of the three general departments of government [must remain] entirely free from the control or coercive influence, direct or indirect, of either of the others,' Humphrey's Executor v. United States, 295 U.S. 602, 629 (1935), the Framers did not require - and indeed rejected - the notion that the three Branches must be entirely separate and distinct.

... In adopting this flexible understanding of separation of powers, we simply have recognized Madison's teaching that the greatest security against tyranny - the accumulation of excessive authority in a single branch - lies not in hermetic division between the Branches, but in a carefully crafted system of checked and balanced power within each Branch. ${ }^{194}$

Additional Court opinions, as well as the opinions of most commentators, have supported this view that the framers and ratifiers adopted a sharing of powers approach to the issue of checks and

193 Garcia, 469 U.S. 528, 530-31 (1985) (Blackmun, J., for the Court) (Fair Labor Standards Act can be applied to city bus drivers), overruling, Usery, 426 U.S. 833, 851 (1976).

194488 U.S. 361, 380-81 (1989). 
balances. ${ }^{195}$ As Justice Kennedy stated in Public Citizen v. United States Dep't of Justice, "This is not to say that each of the three Branches of government must be entirely separate and distinct, for that is not the governmental structure of checks and balances established by the Framers."196

In contrast, Justice Scalia's approach has promoted more of a strict separation of powers approach that is grounded in literal text, with insufficient attention to purpose, context, and history that an impartial spectator approach would require. The text of the Constitution provides: "All legislative Powers herein granted shall be vested in a Congress of the United States"; "The executive Power shall be vested in a President of the United States of America"; "The judicial Power of the United States, shall be vested in one supreme Court, and in such inferior Courts as the Congress may from time to time ordain and establish." Dissenting from the Court's adoption of a sharing of powers approach in Morrison v. Olsen, Justice Scalia stated, "[The majority's opinion] is not analysis; it is ad hoc judgment. And it fails to explain why it is not true - as the text of the Constitution seems to require, . . . all purely executive power must be under the control of the President." 197 Of course, why the literal text here is so important to Justice Scalia, while the literal text of the $11^{\text {th }}$ Amendment is not so important in that context, has never been rationally explained. What is clear is that in all of these cases, Justice Scalia's views reflect the conservative preference for the executive branch and states' rights, while the decisions are not consistent with full consideration of text, purpose, context, history, legislative and executive practice, and precedents from the first 100 years of Court decisions. Scalia's views in these cases thus represent wrongful judicial activism legislating from the bench.

\section{$\underline{\text { V. Conclusion }}$}

As discussed in this article, contemporary debates over values, the so-called "Culture Wars," are best understood not as a debate between religious and secular ideologies, but rather a debate between traditional ideologies, whether religious or secular, which reflect customary or traditional norms, versus progressive ideology, whether religious or secular, which reflect rational deliberation about moral reasoning. Similarly, a major difference among Supreme Court Justices is the extent to which broad terms in the Constitution, like liberty or equality, should be read consistent with customary and traditional beliefs, a view supported by Justices Scalia and Thomas, or should be read in light of the demands of reason, the position of Justices Stevens, Kennedy, Souter, Ginsburg, and Breyer.

Justice Kennedy has observed, "[R] eason, which is the distinguishing mark of the human race, must be embodied in the law if our civilization is to aspire to excellence." 198 In contrast, Justice Scalia

195 See R. Randall Kelso, Separation of Powers Doctrine on the Modern Supreme Court and Four Doctrinal Approaches to Judicial Decision-Making, 20 Pepp. L. Rev. 531, 567-72 (1993).

196491 U.S. 400, 487 (1989) (Kennedy, J., joined by Rehnquist, C.J., and O’Connor, J., concurring).

197487 U.S. 654, 733-74 (1988) (Scalia, J., dissenting).

198 Anthony Kennedy, Commencement Address, University of the Pacific, McGeorge School of Law (May 21, 1988). 
has noted that sometimes reason must give way to customs and traditions based on faith. "We are fools for Christ's sake," Justice Scalia has said, adding that the word cretin, or fool, is derived from the French word for "Christian." He added, "To be honest about it, that is the view of Christians taken by modern society. . . . Surely those who adhere to all or most of these traditional Christian beliefs are to be regarded as simpleminded." 199

As discussed in this article, such individuals are perhaps not simpleminded, but are individuals who base their moral reasoning on less cognitively-advanced concrete operational thought and its support for adolescent peer group morality of customs and traditions, rather than embracing, as did the Founders of our Constitution, and Christ himself, truth and reason as understood from the perspective of adult reason. From the perspective of adult reason, the logic of formal operational thought commits one to the logical and rational elaboration of the biblical imperative of "love of neighbor as oneself," alternative phrased by Adam Smith and the Scottish Enlightenment as behaving according to the logic of an "impartial spectator," or in modern terms, Ronald Dworkin's concept of "equal concern and respect." From this perspective, traditional Christian attitudes which supported slavery, segregation and anti-miscegenation laws, denial of equal rights for women, antiSemitism, rejection of the cosmology of Galileo, rejection of Darwinian evolution, limitations on access to birth control, limitations on stem-cell research, limitations on choice regarding abortion pre-viability, and denial of equal rights to gays and lesbians, among other things, are not consistent with the message of Christ, and instead are the product of thinking at a less cognitively advanced, or in uncharitable terms, ignorant, unchristian manner.

Among the four main ways of interpreting the Constitution - formalist, Holmesian, instrumentalist, and natural law ${ }^{200}$ - Judges who pander to such attitudes, either (1) on grounds that such customs and traditions predominantly define the content of constitutional terms like equal protection and due process, as do formalists like Justices Scalia and Thomas, or (2) on grounds that judges should not in any event choose between alternative conceptions of equal protection and due process, but leave that up to the legislative and executive branches, as did Justice Holmes or Chief Justice Rehnquist, help to support laws based on that less cognitively advanced way of thinking. Under our constitutional tradition, judges should not (3) legislative from the bench and adopt interpretations of the Constitution that merely reflect the judge's view of sound social policy, as some decisions of the instrumentalist Warren Court in the 1960s and Roe v. Wade in the 1970s are accused of doing. However, under our constitutional tradition, judges should (4) read broad natural law concepts like due process and equal protection in light of the most reasoned understanding of those concepts today, as that is how the Founders would have expected them to be interpreted. This is the approach of Justice Kennedy and the other Justices mentioned above who have a clear constitutional commitment to reasoned elaboration of the law. God bless them, and God bless the United States of America.

199 Justice Antonin Scalia: Proud to be a Cretin (http://www.positiveatheism.org/writ/ biblesays.htm\#CRETIN) (April 10, 1996).

200 See R. Randall Kelso, Styles of Constitutional Interpretation and the Four Main Approaches to Constitutional Interpretation in American Legal History, 29 Val. U.L. Rev. 121 (1994). 